Keywords: Saltstone, Shearing, Grout Properties, Bench Scale

Retention: Permanent

\title{
Bench Scale Saltstone Process Development Mixing Study
}

\author{
A.D. Cozzi \\ E.K. Hansen \\ T.M. Jones \\ Y.R. Safford
}

June 2011

Savannah River National Laboratory Savannah River Nuclear Solutions, LLC Aiken, SC 29808

Prepared for the U.S. Department of Energy under contract number DE-AC09-08SR22470. 
SRNL-STI-2011-00346

Revision 0

\section{DISCLAIMER}

This work was prepared under an agreement with and funded by the U.S. Government. Neither the U.S. Government or its employees, nor any of its contractors, subcontractors or their employees, makes any express or implied:

1. warranty or assumes any legal liability for the accuracy, completeness, or for the use or results of such use of any information, product, or process disclosed; or

2. representation that such use or results of such use would not infringe privately owned rights; or

3. endorsement or recommendation of any specifically identified commercial product, process, or service.

Any views and opinions of authors expressed in this work do not necessarily state or reflect those of the United States Government, or its contractors, or subcontractors.

\section{Printed in the United States of America \\ Prepared for \\ U.S. Department of Energy}




\section{REVIEWS AND APPROVALS}

\section{AUTHORS}

A.D. Cozzi, Engineering Process Development

Date

E.K. Hansen, Engineering Process Development

Date

TECHNICAL REVIEWER

D.J. Adamson, Engineering Development Lab

Date

APPROVAL

A.B. Barnes, Manager

Date

Engineering Process Development

S.L. Marra, Manager

Date

Environmental \& Chemical Process Technology Research Programs

J.E. Occhipinti, Manager

Date

Waste Solidification - Engineering 
SRNL-STI-2011-00346

Revision 0

\section{EXECUTIVE SUMMARY}

The Savannah River National Laboratory (SRNL) was requested to develop a bench scale test facility, using a mixer, transfer pump, and transfer line to determine the impact of conveying the grout through the transfer lines to the vault on grout properties. Bench scale testing focused on the effect the transfer line has on the rheological property of the grout as it was processed through the transfer line. Rheological and other physical properties of grout samples were obtained prior to and after pumping through a transfer line.

The Bench Scale Mixing Rig (BSMR) consisted of two mixing tanks, grout feed tank, transfer pump and transfer hose. The mixing tanks were used to batch the grout which was then transferred into the grout feed tank. The contents of the feed tank were then pumped through the transfer line (hose) using a progressive cavity pump. The grout flow rate and pump discharge pressure were monitored. Four sampling stations were located along the length of the transfer line at the 5,105 and 205 feet past the transfer pump and at 305 feet, the discharge of the hose.

Scaling between the full scale piping at Saltstone to bench scale testing at SRNL was performed by maintaining the same shear rate and total shear at the wall of the transfer line. The results of scaling down resulted in a shorter transfer line, a lower average velocity, the same transfer time and similar pressure drops. The condition of flow in the bench scale transfer line is laminar. The flow in the full scale pipe is in the transition region, but is more laminar than turbulent. The resulting plug in laminar flow in the bench scale results in a region of no-mixing. Hence mixing, or shearing, at the bench scale should be less than that observed in the full scale, where this plug is non existent due to the turbulent flow. The bench scale tests should be considered to be conservative due to the highly laminar condition of flow that exists.

Two BSMR runs were performed. In both cases, wall shearing was shown to reduce the rheological properties of the grout as it was processed through the transfer line. Samples taken at the static feed tank showed that gelling impacted the rheological properties of the grout before it was fed into the pump and transfer line. A comparison of the rheological properties of samples taken at the feed tank and transfer line discharge indicated shearing of the grout was occurring in the transfer line.

Bench scale testing of different mixing methods with three different salt solutions showed that method of mixing influences the rheological properties of the grouts. The paddle blade mixing method of the salt solution used for the BMSR testing provided comparable rheological properties of the grout prepared in the BMSR after 14 minutes of processing, B3. The paddle blade mixing method can be used to represent BMSR results and mixing time can be adjusted to represent larger scale mixing. 


\section{TABLE OF CONTENTS}

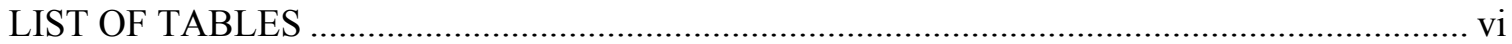

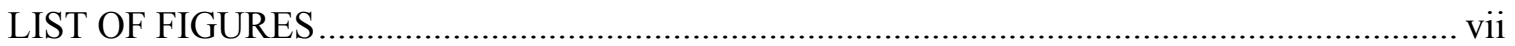

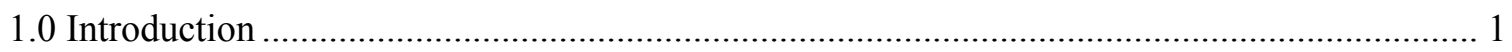

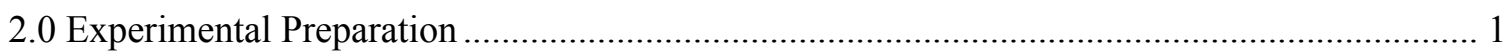

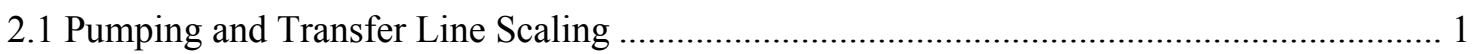

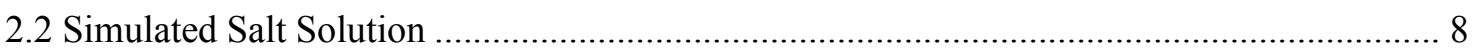

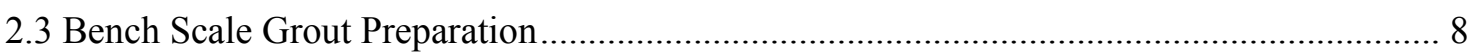

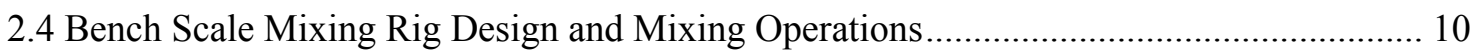

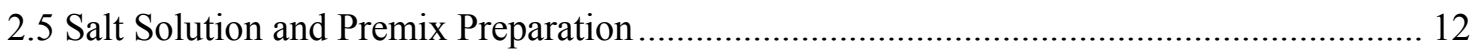

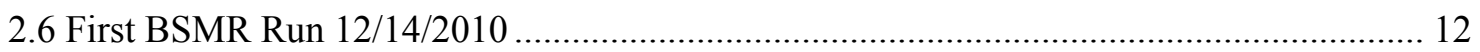

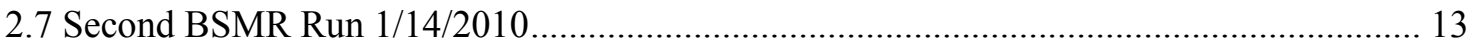

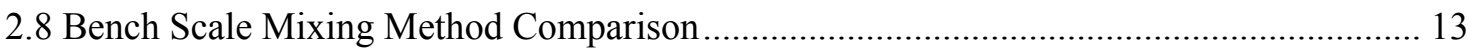

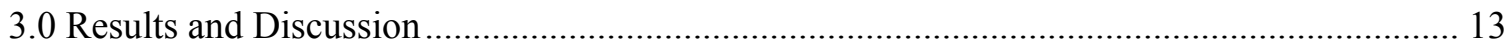

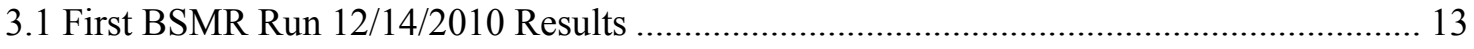

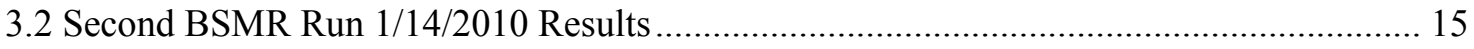

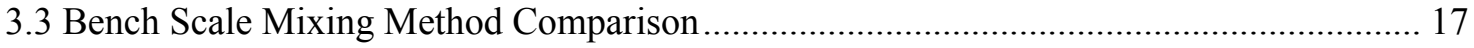

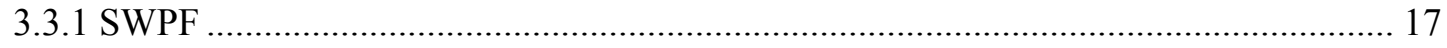

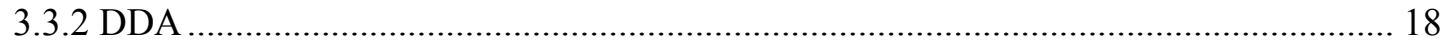

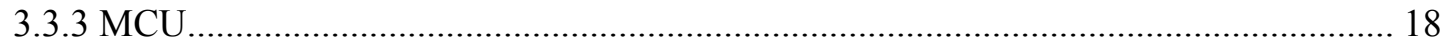

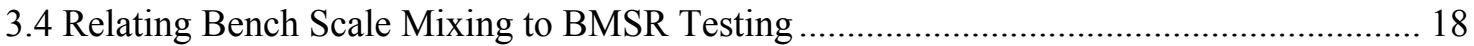

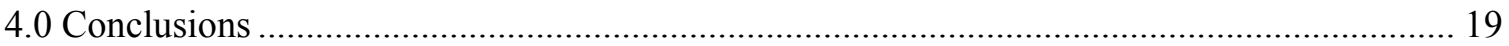

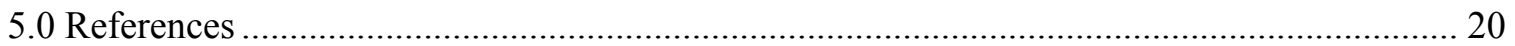

Appendix A - Flow Curves from Conventional Mixing Test ....................................................... 21

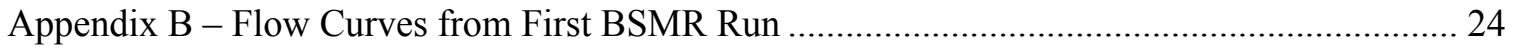

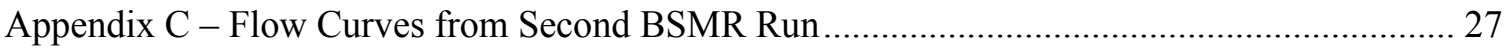




\section{LIST OF TABLES}

Table 1-1 Grout Physical Property and Saltstone Plant Conditions Used for Scaling ................... 1

Table 1-2 Scaling Results for Various Tubing Sizes - Shear Rate and Total Shear Maintained .... 4

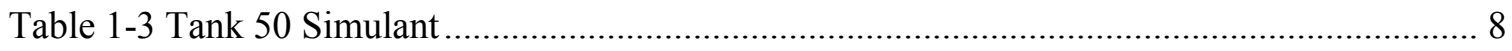

Table 1-4. Paddle Blade Mixing Method. ............................................................................... 9

Table 1-5 BSMR Mixing Station - Conventional Mixing Results ............................................. 12

Table 1-6. Calculated Mass Fractions of Salt Solution and Premix in the BSMR Grouts ............ 12

Table 2-1 First Mixing Test 12/14/2010 Activity Log ........................................................... 14

Table 2-2 First Mixing Test 12/14/2010 Physical Property Results........................................... 15

Table 2-3 First Mixing Test 12/14/2010 Observations of Analyzed Samples .............................. 15

Table 2-4 Second Mixing Test 1/14/2011 Activity Log........................................................... 16

Table 2-5 Second Mixing Test 1/14/2011 Physical Property Results .......................................... 17

Table 2-6 Properties of Salt Simulants Mixed by Different Methods......................................... 19 


\section{LIST OF FIGURES}

Figure 1-1 Total and Laminar Pressure Drop For 3" Schedule 40 Piping...................................... 4

Figure 1-2 Progress Cavity Pump Internal Geometry ............................................................... 5

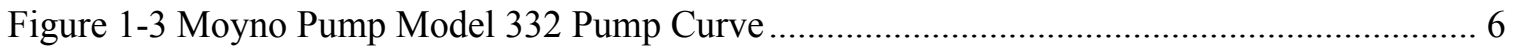

Figure 1-4 Conventional Mixing Grout Stress Vs Mixing Time............................................... 10

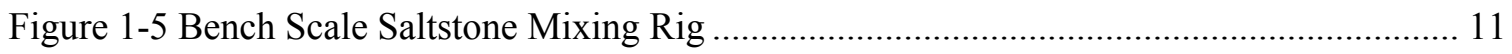

Figure 2-1. Grout flow results of DDA simulant with paddle blade and blender ....................... 17

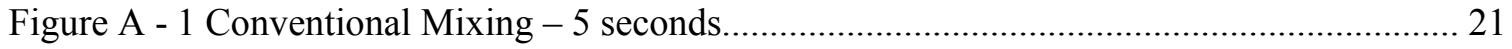

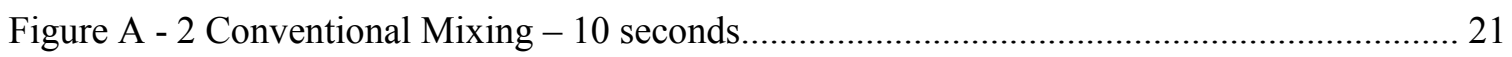

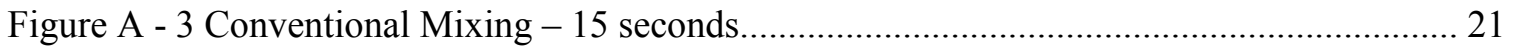

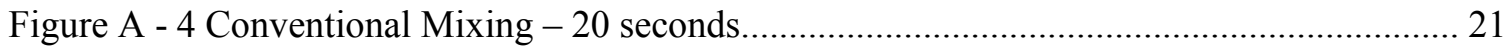

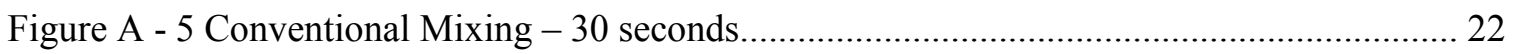

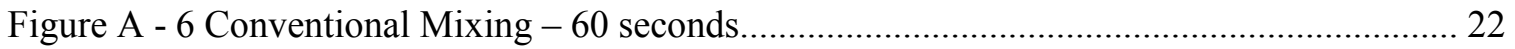

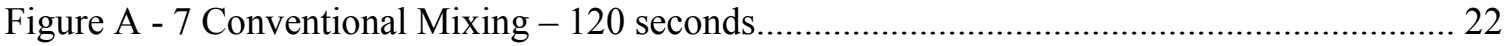

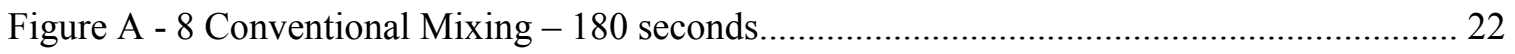

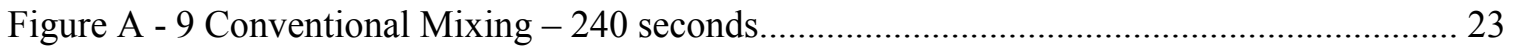

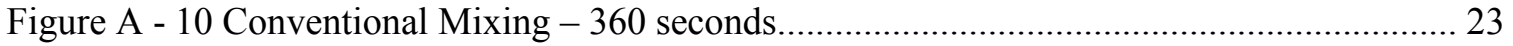

Figure B - 1 BSMR Run 1 - Batch Tank, Sample 1-A …....................................................... 25

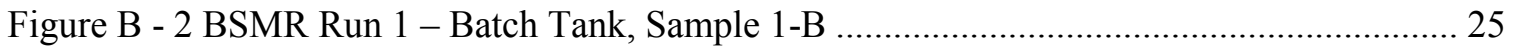

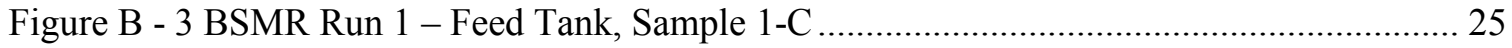

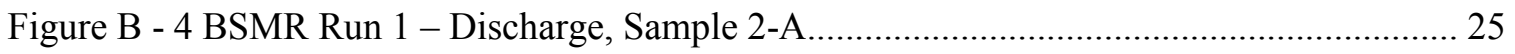

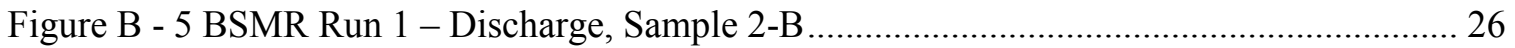

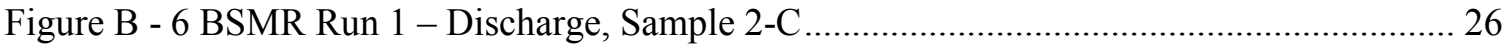

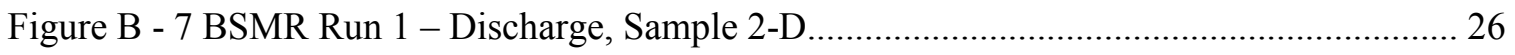

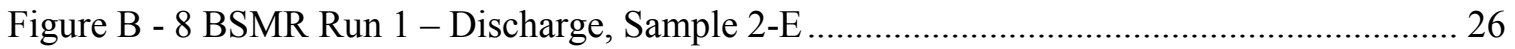

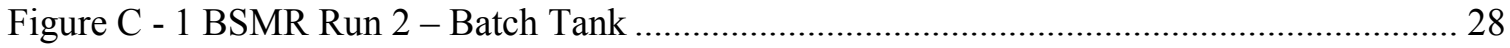

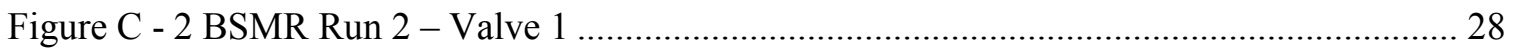

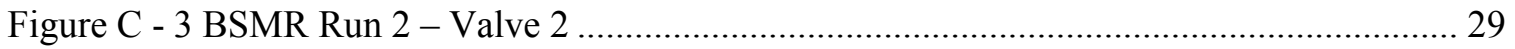

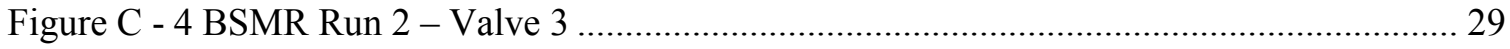

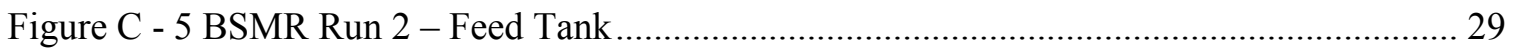

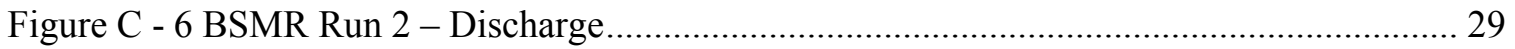




\section{LIST OF ABBREVIATIONS}

$\begin{array}{ll}\text { BSMR } & \text { Bench Scale Saltstone Mixing Rig } \\ \text { CA } & \text { Composite Analysis } \\ \text { DOE } & \text { Department of Energy } \\ \text { ET } & \text { Elapsed time } \\ \text { PA } & \text { Performance Assessments } \\ \text { PCP } & \text { Progressing Cavity Pump } \\ \text { SDF } & \text { Saltstone Disposal Facility } \\ \text { SPF } & \text { Saltstone Production Facility } \\ \text { SRNL } & \text { Savannah River National Laboratory } \\ \text { SRS } & \text { Savannah River Site } \\ \text { w/p } & \text { Water to Premix Ratio } \\ \text { SWPF } & \text { Salt Waste Processing Facility }\end{array}$




\subsection{Introduction}

The Saltstone Product Quality Assurance team was charted in February 2008 to develop a path for identifying the key attributes for processability and long term performance for the grout produced at the Saltstone Production Facility (SPF) and placed in the Saltstone Disposal Facility (SDF) at the Savannah River Site (SRS). One of the variables identified in the report was the uncertainty in how closely the grout formulation process simulates the actual "in-facility" process in the amount of salt solution and flush water, degree of mixing, temperature and other processing attributes. ${ }^{1}$

As part of a multiphase approach to developing a scaled SPF, the Savannah River National Laboratory (SRNL) was requested to develop a bench scale test facility to determine the impact on grout properties of conveying the grout through the transfer lines to the vault. ${ }^{2}$ SRNL developed a bench scale saltstone mixing rig (BSMR), using a conventional mixer and transfer pump to perform initial testing to determine the impact of conveying the grout through the transfer lines and its impact on grout rheology. The rheological and other physical properties obtained from the pumping of the grout through the transfer line will be compared prepared grout prior to being transferred. These results will be compared to properties of simulated saltstone samples mixed using either a paddle blade mixer or a high shear blender ${ }^{3}$.

\subsection{Experimental Preparation}

\subsection{Pumping and Transfer Line Scaling}

It has been assumed that mixing of the grout occurs as it is pumped through the transfer line due to shear associated with the flow. The shearing of the grout results in changes of the rheological properties. In order for the correct amount of shear to be applied to the grout in this task, proper scaling of the transfer line and pumping system were calculated as input to the design of the BSMR.

Scaling the effects the SPF transfer line has on grout properties can be performed using various dynamic relationships, such as wall shear rate, total wall shear, average velocity, Reynolds number $\left(\mathrm{N}_{\mathrm{RE}}\right)$, and Hedstrom number $\left(\mathrm{N}_{\mathrm{HE}}\right)$. The grout properties and SPF plant design data ${ }^{4}$ are provided in Table 2-1. It has been shown that the type of shearing and amount of shearing can affect the physical properties of grout. $^{5}$

Table 2-1 Grout Physical Property and Saltstone Plant Conditions Used for Scaling

\begin{tabular}{|c|c|c|}
\hline \multirow{3}{*}{ Grout Property } & Yield Stress (Pa) & 7.4 \\
\cline { 2 - 3 } & Plastic Viscosity (cP) & 56 \\
\cline { 2 - 3 } & Density (g/mL) & 1.7 \\
\hline \multirow{3}{*}{ Plant Design } & Pipe Diameter (in) & 3.068 \\
\cline { 2 - 3 } & Pipe Length (ft) & 3000 \\
\cline { 2 - 3 } & Average Flow rate (gpm) & 150 \\
\hline
\end{tabular}

For scaling purposes, the decision was to use the shear rate (or shear stress) at the wall for scaling, since this is greatest shear rate in the piping. It was assumed that the condition of flow is either laminar or transitional. Since the wall shear rates were the same, the total applied shear must also be the same in the two scales so as to apply the same quantity of mixing (due to only 
wall shear). In the following calculations the shear rate and total shear rate in the transfer line were maintained between the saltstone condition and various sized hoses.

The equations ${ }^{6,7,8,9,10}$ [1] through [16] were used to support calculating the average velocity, Reynolds number, Hedstrom number, Transition Reynolds number (point at which flow starts to transition between laminar to turbulent), pressure drop, wall shear rate, wall shear stress, time of flight, total shear, volume in the transfer line, and power (for pumping only - no losses due to heat or internal recirculation) per unit volume for the Saltstone transfer line and potential hose sizes that could be used for testing. Additional assumptions made were that the physical properties do not change with time, no slip condition at pipe/hose surface and scaling was on flow in pipe/hose only. Shearing from other surfaces or equipment was ignored.

$$
\begin{aligned}
& \text { Average Velocity } \Rightarrow \bar{v}=\frac{4 \cdot \dot{Q}}{\pi \cdot d^{2}}, \\
& \text { Reynolds Number } \Rightarrow N_{R E}=\frac{\rho \cdot \bar{v} \cdot d}{\mu_{\infty}}, \\
& \text { Hedstrom Number } \Rightarrow N_{H E}=\frac{D^{2} \cdot \rho \cdot \tau_{o}}{\mu_{\infty}^{2}} \\
& \text { Transition Reynolds Number } \Rightarrow \quad N_{T R E}=\frac{N_{H E}}{8 \cdot x_{c}}\left(1-\frac{4}{3} x_{c}+\frac{1}{3} x_{c}^{4}\right) \\
& \frac{x_{c}}{\left(1-x_{c}\right)^{3}}=\frac{N_{H E}}{16800} \\
& \text { Ratio of Reynolds Number } \Rightarrow R_{R E}=\frac{N_{R E}}{N_{T R E}}
\end{aligned}
$$

Fanning Friction Factor

$$
\begin{gathered}
f_{L}=\frac{16}{N_{R E}}\left[1+\frac{1}{6} \frac{N_{H E}}{N_{R E}}-\frac{1}{3} \frac{N_{H E}^{4}}{f_{L}^{3} \cdot N_{R E}^{7}}\right] \text { (laminar) } \\
f_{T}=\frac{10^{a}}{N_{R E}^{0.193}}, a=-1.47\left[1-0.146 e^{-2.9 \times 10^{-5} N_{H E}}\right] \text { (turbulent) } \\
f=\left(f_{L}^{m}+f_{T}^{m}\right)^{\frac{1}{m}}, m=1.7+\frac{40,000}{N_{R E}} \text { (total) }
\end{gathered}
$$$$
\text { Pressure Drop } \Rightarrow \Delta P=\frac{2 \cdot f \cdot L \cdot \rho \cdot \bar{v}^{2}}{d} \text { (pressure drop) }
$$$$
\text { Wall shear stress } \Rightarrow \tau_{w}=\frac{d \cdot \Delta P}{4 L}
$$$$
\text { Shear rate } \Rightarrow \dot{\gamma}_{w}=\frac{\tau_{w}-\tau_{o}}{\mu_{\infty}}
$$$$
\text { Plug ratio } \Rightarrow P R=\frac{\tau_{o}}{\tau_{w}}
$$ 
Time of flight $\Rightarrow t=\frac{L}{\bar{v}}$

Total wall shear $\Rightarrow S=\dot{\gamma}_{w} \cdot t$

Volume in line $\Rightarrow V=\frac{\pi}{4} \cdot d^{2} \cdot L$

Power per unit volume $\Rightarrow \frac{P}{V}=\frac{9.8 \cdot \dot{Q} \cdot \Delta H \cdot \rho}{V}$

Where: $\quad \overline{\mathrm{v}}=$ average pipe velocity

$\dot{\mathrm{Q}}=$ volumetric flow rate

$\mathrm{d}=$ inside diameter of pipe or hose

$\rho=$ density of grout

$\mu_{\infty}=$ Bingham Plastic viscosity or infinite viscosity of grout

$\tau_{\mathrm{o}}=$ Bingham Plastic yield stress

$\mathrm{L}=$ Pipe length

Typical and readily available hose sizes of inside diameters of $3 / 8,1 / 2,5 / 8,3 / 4$ and 1 -inch were evaluated for use in the BSMR and the results are provided in Table 2-2. The wall shear rate is $250.5 \mathrm{sec}^{-1}$ and the total shear is $57725 \mathrm{sec}^{-1}$ and maintained as the basis for scaling. In all cases, the plug ratio $(0.345)$ and time of flight $(230 \mathrm{sec})$ were the same and is consistent with the above equations. The analysis indicates that as the inside diameter becomes smaller, the velocity, Hedstrom, Reynolds, and ratio of Reynolds numbers decrease and the flow is laminar. The laminar flow conditions have the same shear rate profiles given the constant wall shear rate. ${ }^{11}$ For the 3" pipe, the condition of flow is in the transitional region, but it is more laminar than turbulent, as can be observed in Figure 2-1, where the pressure drop for only laminar flow is almost that of the combined pressure drop due to laminar/turbulent at 150 GPM. The plug ratio for the 3" pipe is questionable, since this assumption only holds true for laminar flow and in the plug region there is no velocity gradient and therefore no shearing or mixing. For the 3" pipe, this plug area is most likely less than that calculated, thus a larger active zone of mixing. Hence, the mixing on the smaller scales would be conservative (less mixing) as compared to the 3" pipe. SRNL selected using the 5/8-inch ID tubing since the quantity of material is manageable and the flow rate provides adequate time to pull samples during the test.

The process of scaling down resulted in a shorter transfer line, a lower target flow velocity, the same transfer time and slightly larger pressure drop and power per unit volume. The reason for the difference in pressure drop and power per unit volume is the flow condition in the 3" pipe is in transition between laminar and turbulent. Assuming transition of flow condition allows the shear stress/rate to be determined directly from equations [10] and [11] without correction. If the flow condition in the 3" pipe was only laminar, the pressure drop would be smaller, resulting in a smaller wall shear stress and shear rate. 
SRNL-STI-2011-00346

Revision 0

Table 2-2 Scaling Results for Various Tubing Sizes - Shear Rate and Total Shear Maintained

\begin{tabular}{|c|c|c|c|c|c|c|c||}
\hline \multirow{2}{*}{ Parameter } & \multirow{2}{*}{ Units } & \multirow{2}{*}{$\mathbf{3}$ Sch. } & \multicolumn{5}{|c|}{ Inside Diameter of Tubing } \\
\cline { 6 - 9 } & & $\mathbf{4 0}$ & $\mathbf{1}$ & $\mathbf{3 / 4}$ & $\mathbf{5 / 8}$ & $\mathbf{1 / 2}$ & $\mathbf{3 / 8}$ \\
\hline Inside Diameter $(\mathrm{D})$ & Inches & 3.068 & 1 & 0.75 & 0.625 & 0.5 & 0.375 \\
\hline Volumetric flow rate $(\dot{\mathrm{Q}})$ & $\mathrm{GPM}$ & 150.0 & 5.31 & 2.24 & 1.30 & 0.66 & 0.28 \\
\hline Average velocity $(\overline{\mathrm{V}})$ & $\mathrm{ft} / \mathrm{sec}$ & 6.51 & 2.17 & 1.63 & 1.36 & 1.09 & 0.82 \\
\hline Pipe Run $(\mathrm{L})$ & $\mathrm{Ft}$ & 1500 & 500 & 375 & 312 & 250 & 187 \\
\hline Hedstrom number $\left(\mathrm{N}_{\mathrm{HE}}\right)$ & Unitless & 24360 & 2588 & 1456 & 1011 & 647 & 364 \\
\hline Reynolds number $\left(\mathrm{N}_{\mathrm{RE}}\right)$ & Unitless & 4694 & 511 & 287 & 200 & 128 & 72 \\
\hline $\begin{array}{c}\text { Transition Reynolds number }( \\
\left.\mathrm{N}_{\mathrm{TRE}}\right)\end{array}$ & Unitless & 4281 & 2537 & 2366 & 2291 & 2226 & 2173 \\
\hline $\begin{array}{c}\text { Ratio of Reynolds number }( \\
\left.\mathrm{N}_{\mathrm{RE}}\right)\end{array}$ & Unitless & 1.10 & 0.20 & 0.12 & 0.09 & 0.06 & 0.03 \\
\hline $\mathrm{N}_{\mathrm{TRE}}$ & & & & & & & \\
\hline Pressure Drop $(\Delta \mathrm{P})$ & Psi & 72.9 & 74.6 & 74.6 & 74.6 & 74.6 & 74.6 \\
\hline Volume in line $(\mathrm{V})$ & Gallons & 576 & 20.4 & 8.6 & 5.0 & 2.5 & 1.1 \\
\hline Power Per Unit Volume $\left(\frac{\mathrm{P}}{\mathrm{V}}\right)$ & W/m & 2.23 & 2.28 & 2.28 & 2.28 & 2.28 & 2.28 \\
\hline \hline
\end{tabular}

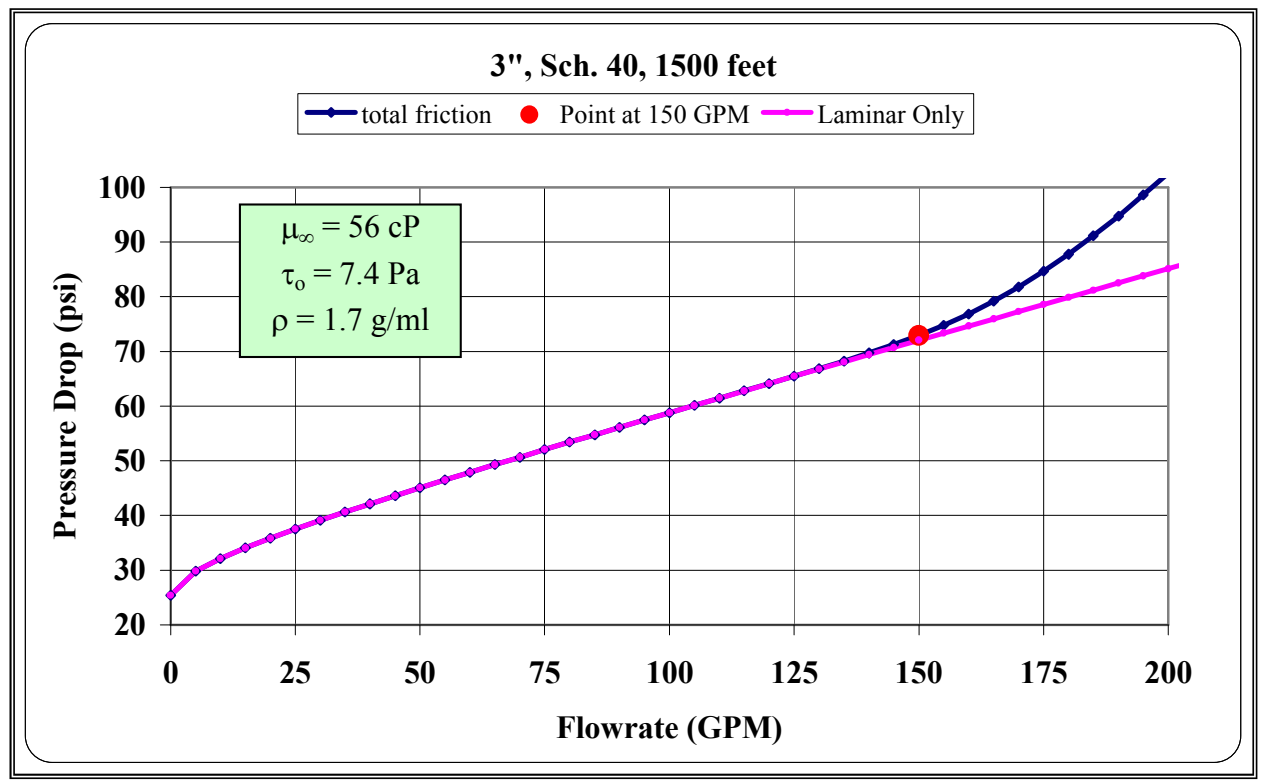

Figure 2-1 Total and Laminar Pressure Drop For 3" Schedule 40 Piping

Shearing of the grout in the BSMR occurs wherever there is a velocity gradient. Hence, shearing is experienced throughout the BSMR and is low to non-existent in the hold tank such that essentially all shearing is provided by the transfer system. The transfer system includes the pump and transfer line. The shearing contributed by the transfer line (the wall shear rate) determined above is $250.5 \mathrm{sec}^{-1}$ and the total shear is $57725 \mathrm{sec}^{-1}$. 
The other component in the BSMR transfer system that provides shearing is the transfer pump. ${ }^{*} \mathrm{~A}$ progressing cavity pump consists of a screw and a sleeve as shown in Figure 2-2. The cavity (volume of fluid) between the stator and rotor, for a given pitch P, centerline eccentricity e, and rotor diameter $\mathrm{D}$ is $4 \mathrm{eDP}$ per revolution. For the transfer pump, the pitch is approximately 3.6 inches, the rotor diameter is 1 inch, and the linear contact length $(\lambda)$ between the stator and rotor is 3 inches, as measured.

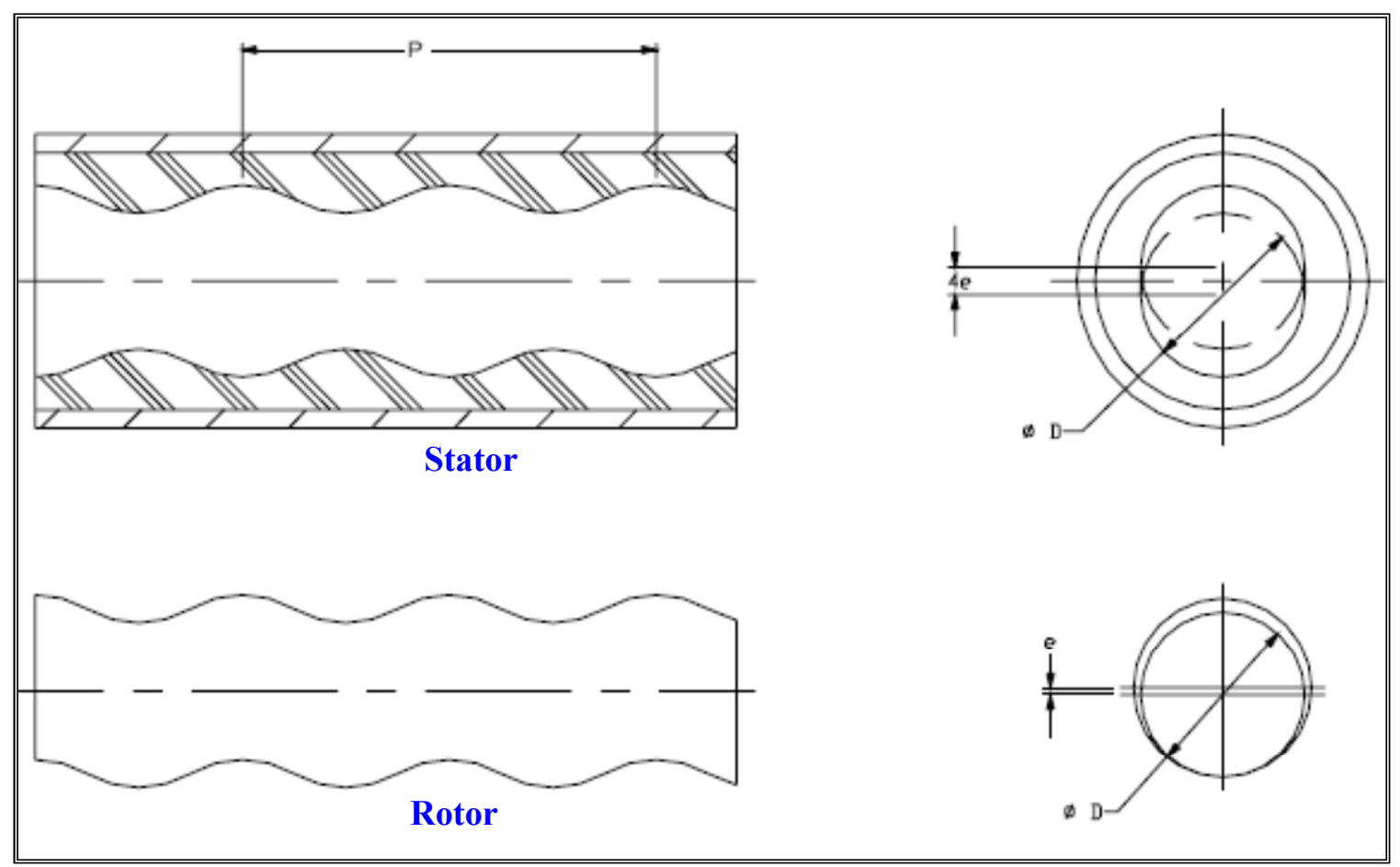

Figure 2-2 Progress Cavity Pump Internal Geometry

The pump curve for the transfer pump is provided in Figure 2-3. For a flow rate of 1.25 GPM (as targeted in the BSMR runs), the operating speed ranged between 480 to 1000 RPM. In the $2^{\text {nd }}$ run, the operating speed ranged between 800 to 1000 RPM, yielding a discharge pressure ranging between 0 and 100 psi. The decrease in flow as the discharge pressure increased was due to recirculation of the fluid between the stator and rotor and can be minimized by increasing the linear contact length, $\lambda$ (i.e. use a pump with a longer stator/rotor section).

* Moyno Pump model 332 progressing cavity pump (PCP) 
SRNL-STI-2011-00346

Revision 0

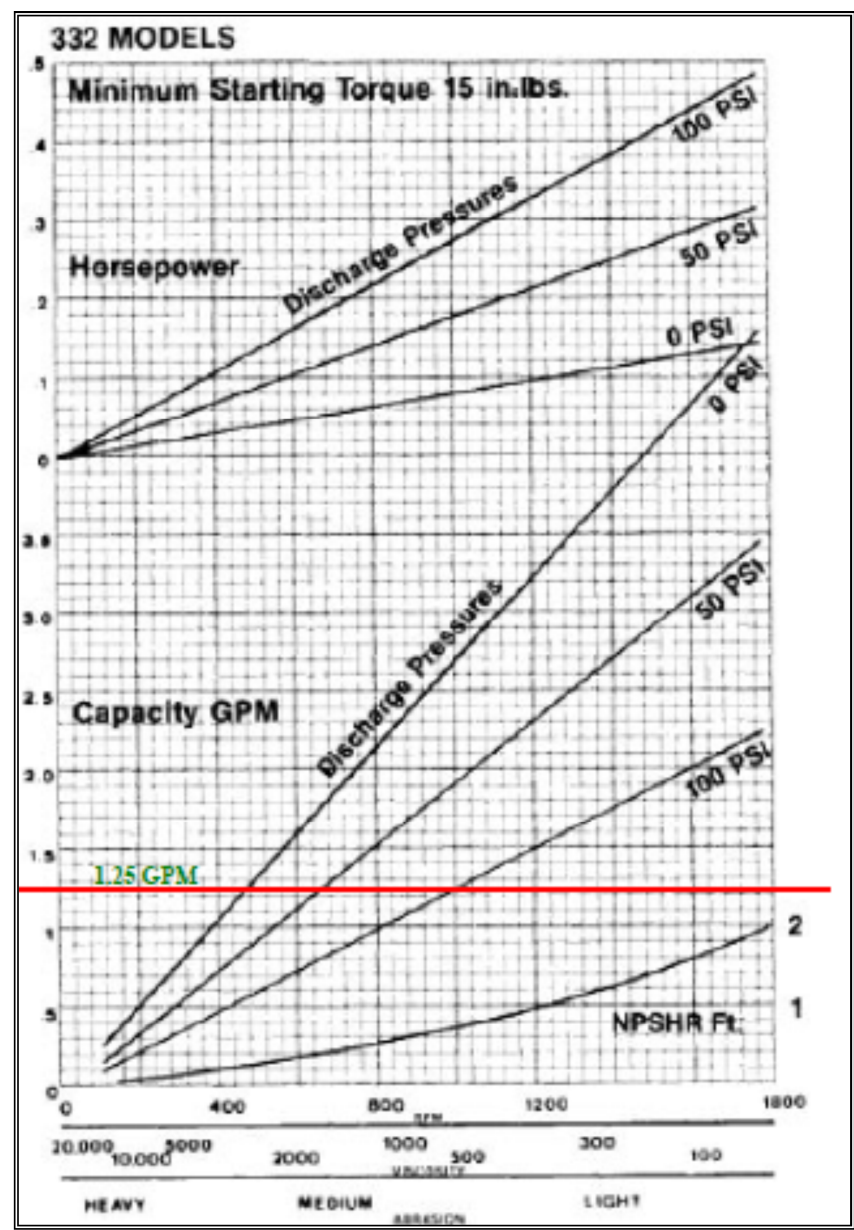

Figure 2-3 Moyno Pump Model 332 Pump Curve

For a zero discharge pressure condition-maximum flow for a given pump speed - the flow through a PCP is shown as equation [17]. Review of Figure 2-3 shows this to be the case, if one were to follow a constant speed line, $800 \mathrm{rpm}$ for example, at $100 \mathrm{psi}$, the flow rate is $1 \mathrm{gpm}$ and at 0 psi the flow rate is $2.15 \mathrm{gpm}$ and the reduction of discharge flow due to recirculation in the rotor/stator from expansion of the stator as pressure increases.

$$
\text { Maximum flow through } \mathrm{PCP} \Rightarrow \dot{Q}_{\max , P C P}=4 e D P \dot{\Omega},
$$

where $\dot{\Omega}$ is the rotational speed of the rotor. The product $4 \mathrm{eD}$ can be considered as the "averaged" cross section of a cavity section and the above equation can be written as,

$$
\dot{Q}_{\max , P C P}=A_{P C P} P \dot{\Omega},
$$

The actual flow rate through the pump is given as,

$$
\dot{Q}_{P C P}=A_{P C P} \dot{v}_{P C P},
$$

Equating equations [18] and [19] and solving for the velocity of the fluid in the PCP, the result is, 


$$
\dot{v}_{P C P}=\frac{\dot{Q}_{P C P}}{\dot{Q}_{\max , P C P}} P \dot{\Omega},
$$

The time in which the fluid spends time between the rotor and stator is shown in equation [21]. As the flow rate decreases for a specific rotor speed, the time the fluid spends in the pump increases.

$$
t_{P C P}=\frac{\lambda}{\dot{v}_{P C P}}=\frac{\lambda}{P \dot{\Omega}} \frac{\dot{Q}_{\max , P C P}}{\dot{Q}_{P C P}},
$$

From Figure 2-3, for a targeted flow rate of 1.25 GPM and maximum rotational speed of 1000 RPM (for maximum discharge pressure), the maximum flow rate is 3.7 GPM at zero discharge pressure. The time for the fluid to pass through the pump at $1.25 \mathrm{GPM}$ is;

$$
t_{P C P}=\frac{3}{3.6 \cdot 1000 \frac{1}{\min }} \frac{3.7}{1.25}=0.0025 \mathrm{~min}=0.148 \mathrm{sec}
$$

The time the fluid spends in the pump is much smaller than the time the fluid is pumped through the transfer line, which is 230 seconds.

Shear rate information based on how large a particle PCP's can process was obtained for a similar pump..$^{\dagger}$ The size of the cavity, or specifically the eccentricity, determines the maximum particle size that can be transported. For this transfer pump, t particles as large as 0.125 inches can be processed. The technical data for Roper PCP for maximum particle sizes of 0.08 and 0.15 inches, the shear rate is 148.5 and $92.9 \mathrm{sec}^{-1}$ respectively per $100 \mathrm{RPM}$. For conservatism and unknowns between PCP vendor designs, SRNL will utilize $200 \mathrm{sec}^{-1} / 100$ RPM to determine shear rate and total shear provided by the pump as equation [23] and [24] respectively.

$$
\begin{aligned}
& \dot{\gamma}_{P C P}=\frac{200 \mathrm{sec}^{-1}}{100 R P M} \cdot 1000 R P M=2000 \frac{1}{\mathrm{sec}}, \\
& \gamma_{P C P}=\dot{\gamma}_{P C P} \cdot t_{P C P}=\frac{2000}{\mathrm{sec}} 0.148 \mathrm{sec}=296,
\end{aligned}
$$

Though the shear rate in the pump (2000 $\left.\mathrm{sec}^{-1}\right)$ is high as compared to the shear rate in the transfer line $\left(256 \mathrm{sec}^{-1}\right)$, the fluid residence time in the pump $(0.148 \mathrm{sec})$ is very short compared to the time the fluid spends in the transfer line (230 seconds). Comparing the total shear (57725) applied by shearing from the wall to the contribution of shearing from the pump (296), it is expected that the shearing contribution from the pump to be negligible in the BSMR.

\footnotetext{
${ }^{\dagger}$ Moyno does not make shear rate information available for this product. Data was obtained from the Roper Pump Company.
} 
At this high shear rate, the apparent viscosity of a grout as it passes through this pump is close to the plastic viscosity. Correcting for the effect of viscosity would be minimal for pump performance.

\section{$\underline{2.2}$ Simulated Salt Solution}

The Tank $50 \mathrm{H}$ salt solution simulant that has been used to support various Vault 4 Cell E Core saltstone grout activities at SRNL was used throughout this task. The simulant composition is shown in Table 2-3. Batches acceptability was confirmed when the density and total solids were within $1.223+/-0.005 \mathrm{~g} / \mathrm{ml}$, and $28.0 \mathrm{wt} \%+/-0.5 \mathrm{wt} \%$ respectively throughout this task.

Table 2-3 Tank 50 Simulant

\begin{tabular}{|c|c|c|}
\hline \multicolumn{2}{|c|}{ BATCH SHEET FOR Tank 50 SIMULANT 11-30-2007 WCS Analysis } \\
\hline Compound & Molarity & Mass $(\mathrm{g})$ for one Liter \\
\hline De-ionized - Water $\left(\mathrm{H}_{2} \mathrm{O}\right)$ & - & 809.25 \\
\hline $\mathrm{NaNO}_{3}$ & 2.879 & 244.51 \\
\hline $\mathrm{Na}_{2} \mathrm{C}_{2} \mathrm{O}_{4}$ & 0.008 & 1.01 \\
\hline $\mathrm{Na}_{2} \mathrm{SO}_{4}$ & 0.004 & 0.63 \\
\hline $\mathrm{Na}_{2} \mathrm{Al}_{2} \mathrm{O}_{4} \times 2 \mathrm{H}_{2} \mathrm{O}(\mathrm{Al}$ molarity) & 0.127 & 10.42 \\
\hline $\mathrm{Al}_{\left(\mathrm{NO}_{3}\right)_{3} \times \mathrm{H}_{2} \mathrm{O}(\mathrm{Al} \text { molarity })}$ & 0.120 & 45.31 \\
\hline $\mathrm{Na}_{3} \mathrm{PO}_{4} \times 12 \mathrm{H}_{2} \mathrm{O}$ & 0.002 & 0.90 \\
\hline $50.5 \%$ by Weight $\mathrm{NaOH}_{\mathrm{NaNO}}$ & 1.292 & 102.33 \\
\hline $\mathrm{NaNO}_{2}$ & 0.032 & 2.20 \\
\hline $\mathrm{Na}_{2} \mathrm{CO}_{3}$ & 0.053 & 5.64 \\
\hline
\end{tabular}

\section{$\underline{2.3}$ Bench Scale Grout Preparation}

The goal of the bench scale mixing task was to determine the conditions under which the BSMR grouts is prepared. The main requirement of the bench scale grout preparation is to provide the BMSR with a grout with rheological properties that are affected by additional shear applied after the initial mixing. Therefore, an understanding as to how mixing times affect rheology given a fixed time of premix addition to the mix and constant agitator speed.

In these tests, 468.5 grams of salt solution was added to a 1-Liter beaker. The salt solution was agitated with a mixer fitted with a Rushton impeller rotating at set to $250 \mathrm{rpm}$. Next, 531.5 grams dry premix blend (10 wt \% cement, $45 \mathrm{wt} \%$ slag, and $45 \mathrm{wt} \%$ fly ash) was added to the salt solution over approximately 30 seconds. The mixer was stopped to allow air to be released from the mix. The mixer was restated with the speed set to $580 \mathrm{rpm}$. When the set speed was reached, mixing was continued for a predetermined length of time. At the conclusion of the specific mixing time, the grout was analyzed using a flow curve (to determine Bingham Plastic yield stress, plastic viscosity and change in shear stress at maximum shear rate), flow, gel time, set time and volume percent bleed water. The difference at maximum shear rate provides an indication that additional shearing will continue to reduce the rheological properties. The flow in the bob/cup geometry used to measure the rheology was laminar for all the samples analyzed. The grout temperature was also measured immediately upon the conclusion of mixing. The premix addition times, mixing times, physical properties and temperature data are provided in Table 2-4. Evaluation of the yield stress data, shown in Figure 2-4, shows that this grout was sensitive to mixing (or shear) to about 60 seconds of mixing, at which point additional shearing or mixing 
does little to make it rheologically thinner. This conclusion is also supported by the flow data. The flow data clearly suggested that once the grout had been mixed to support the BSMR using the conventional method, it should be delivered to the BSMR hold tank for use and mixing of the product should be between 15 to 30 seconds time. This would provide a grout that is sensitive to shear such that shearing caused by the transfer line would be evident. Note that the gel time for this grout was fairly short, which for stagnate conditions in the BSMR process would result in a more viscous grout. No rheological measurements were performed to determine the effect gel or static setting time has on these properties. The flow curves for each batch are located in Appendix A.

Table 2-4. Paddle Blade Mixing Method.

\begin{tabular}{|c|c|c|c|c|c|c|c|c|c|c|}
\hline \multirow{3}{*}{$\begin{array}{c}\text { Batch } \\
\quad \#\end{array}$} & \multirow{3}{*}{$\begin{array}{l}\text { Mixing } \\
\text { Time } \\
(\mathrm{sec})\end{array}$} & \multirow{3}{*}{$\begin{array}{c}\text { Premix } \\
\text { addition } \\
\text { time } \\
(\mathrm{sec})\end{array}$} & \multirow{3}{*}{$\begin{array}{l}\text { Temp } \\
\text { at end } \\
\left({ }^{\circ} \mathrm{C}\right)\end{array}$} & \multicolumn{5}{|c|}{ Flow Curve Results } & \multirow{3}{*}{$\begin{array}{c}\text { Flow } \\
\text { Cylinder } \\
\text { (cm) }\end{array}$} & \multirow{3}{*}{$\begin{array}{l}\text { Gel } \\
\text { Time } \\
\text { (min) }\end{array}$} \\
\hline & & & & \multicolumn{2}{|c|}{ Up } & \multicolumn{2}{|c|}{ Down } & \multirow{2}{*}{$\begin{array}{c}\Delta \text { stress } \\
\quad \text { at } \\
300 \mathrm{~s}^{-1} \\
(\mathrm{~Pa})\end{array}$} & & \\
\hline & & & & $\begin{array}{l}\mathrm{PV}^{*} \\
(\mathrm{cP})\end{array}$ & $\begin{array}{l}\mathrm{YS}^{* *} \\
(\mathrm{~Pa})\end{array}$ & $\begin{array}{l}\mathrm{PV}^{*} \\
(\mathrm{cP})\end{array}$ & $\begin{array}{c}\mathrm{YS}^{* *} \\
(\mathrm{~Pa})\end{array}$ & & & \\
\hline 1 & 5 & 33 & 16.8 & 69.9 & 9.1 & 70.4 & 4.8 & 1.31 & 25.5 & $<8$ \\
\hline 2 & 10 & 30 & 16.8 & 72.9 & 9.1 & 76.4 & 5.2 & 1.38 & 26.2 & $<6$ \\
\hline 3 & 15 & 30 & 18.2 & 70.4 & 6.2 & 67.8 & 5.4 & 0.69 & 27.0 & $<7$ \\
\hline 4 & 20 & 30 & 18.6 & 73.1 & 6.6 & 69.6 & 5.8 & 0.69 & 26.5 & $<7$ \\
\hline 5 & 30 & 30 & 18.4 & 73.4 & 6.8 & 70.1 & 6.2 & 0.69 & 26.9 & $<7$ \\
\hline 6 & 60 & 30 & 18.2 & 69.5 & 4.6 & 63.4 & 6.1 & 0.08 & 27.0 & $<7$ \\
\hline 7 & 120 & 30 & 18.4 & 67.8 & 5.0 & 61.2 & 6.8 & -0.08 & 27.0 & $<7$ \\
\hline 8 & 180 & 30 & 18.8 & 67.3 & 4.7 & 60.1 & 6.8 & -0.15 & 26.8 & $<7$ \\
\hline 9 & 240 & 30 & 19.2 & 65.2 & 5.4 & 58.2 & 7.2 & -0.08 & 26.7 & $<6$ \\
\hline 10 & 360 & 30 & 19.6 & 68.2 & 6.2 & 60.9 & 7.7 & 0.23 & 26.0 & $<5$ \\
\hline
\end{tabular}

* PV = plastic viscosity, ** YS = Yield Stress 


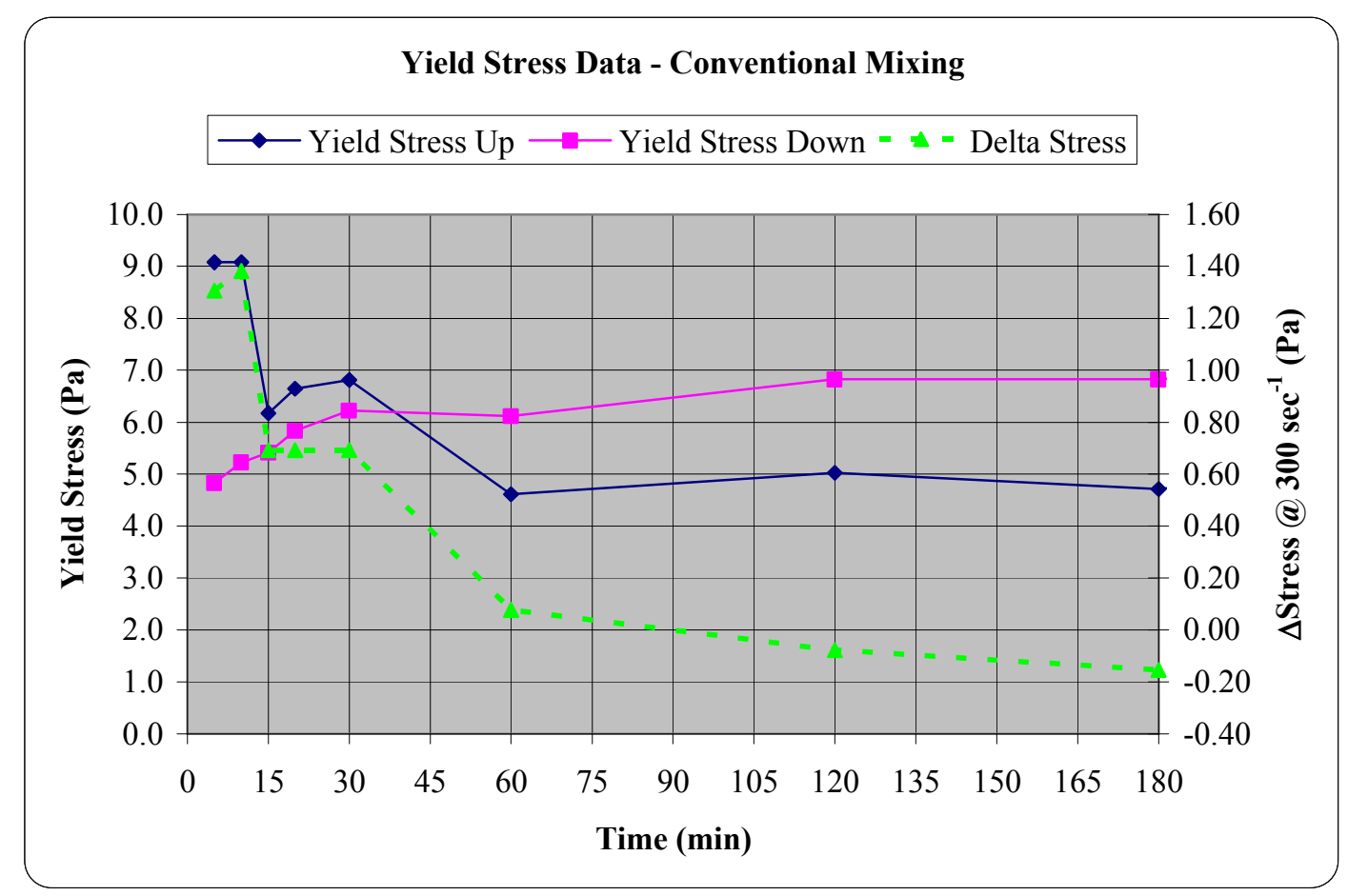

Figure 2-4 Conventional Mixing Grout Stress Vs Mixing Time

\subsection{Bench Scale Mixing Rig Design and Mixing Operations}

The BSMR consisted of two conventional mixing tanks, grout feed tank, transfer pump, and transfer hose, as conveyed in Figure 2-5. The conventional mixing tanks were used to combine the pre-blended dry premix with the salt simulant solution. The wetted grout was then placed into the grout feed tank. The contents of the feed tank were then pumped through the transfer line (tubing) using a progressive cavity pump. The flow rate and pump discharge pressure were measured. Four sampling stations were located along the length of the transfer line at the 5, 105 and 205 feet lengths past the transfer pump and at the tubing discharge, 305 feet from the transfer pump. 


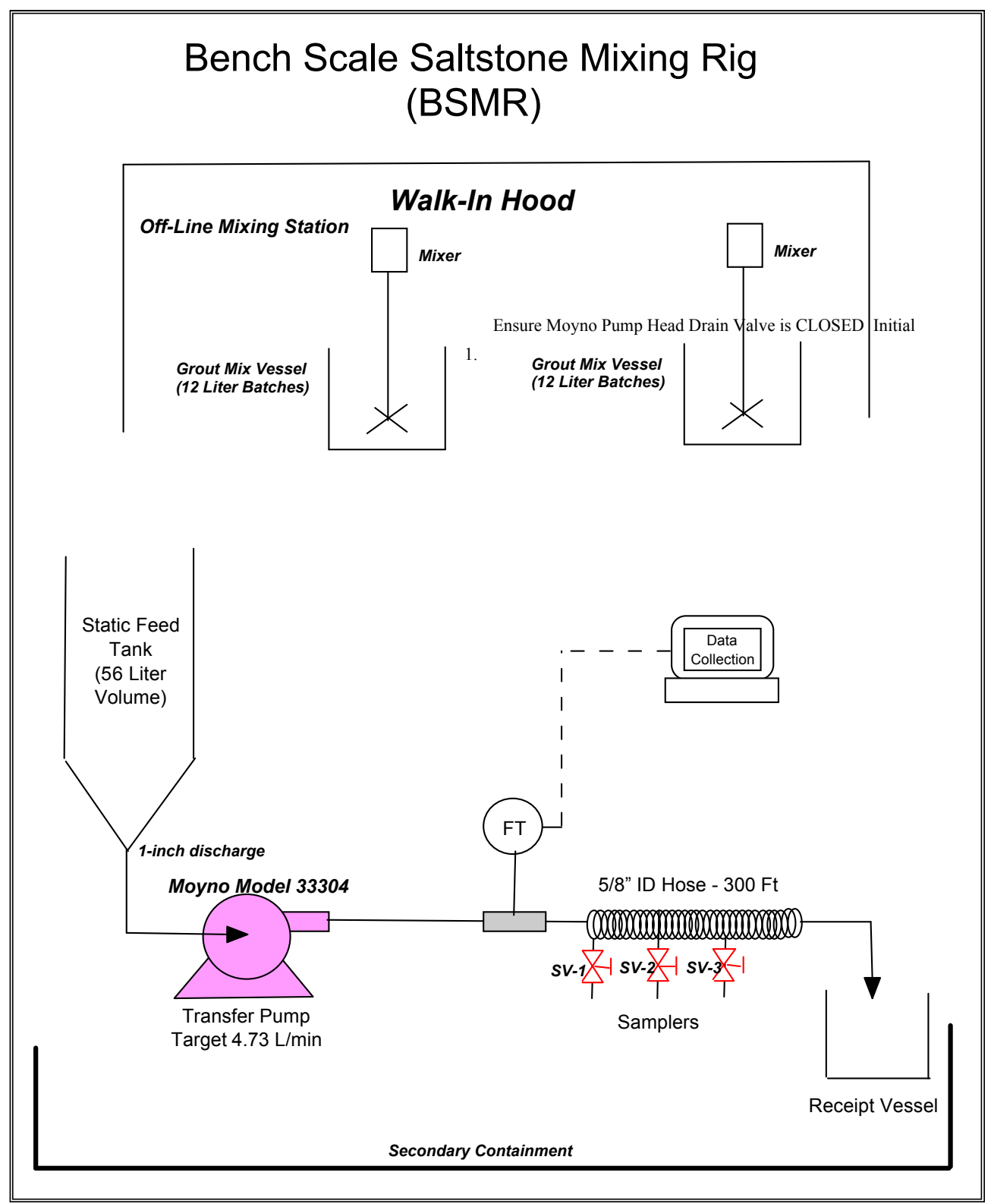

Figure 2-5 Bench Scale Saltstone Mixing Rig

The mixing station consisted of two Caframo ${ }^{\mathrm{TM}}$ mixers that were used to prepare the 3-gallon grout batches. Four runs were conducted to determine the necessary mixing configuration to provide a grout mixture. A targeted grout volume batch of 3 gallons was used in all the BSMR activities. The salt simulant solution was first placed into a clean 5-gallon bucket and placed under the mixer. Pre-weighed premix that provided the necessary $\mathrm{w} / \mathrm{p}$ ratio in plastic bags were added to the simulant solution as the salt simulant solution was being mixed. Four different trials were necessary to determine the mixing condition required to support the BSMR. Trial \#4 was adopted as the standard method for preparing the grout for the BSMR. 
Table 2-5 BSMR Mixing Station - Conventional Mixing Results

\begin{tabular}{|c|l||}
\hline $\begin{array}{c}\text { Trial } \\
\#\end{array}$ & \multicolumn{1}{|c||}{ Summary } \\
\hline 1 & $\begin{array}{l}\text { 3" diameter Rushton impeller. Mixing was insufficient to incorporate the premix } \\
\text { powder into the simulant solution. }\end{array}$ \\
\hline 2 & $\begin{array}{l}3.5 \text { " diameter Rushton impeller. Premix incorporation was improved but clumps were } \\
\text { present in grout after mixing at 500 rpm for a total mixing time of four minutes. }\end{array}$ \\
\hline 3 & $\begin{array}{l}\text { 5" diameter A-320 impeller. Initial agitator speed of 350 rpm and was increased to 500 } \\
\text { rpm during premix addition. Premix was added in 30 seconds, resulting in the mixer } \\
\text { motor to shut off in an over-torqued condition. Motor restarted and grout mixed for an } \\
\text { additional 30 seconds. Grout appeared wetted on the surface, however there were a few } \\
\text { small clumps observed in the grout while it was being poured out. }\end{array}$ \\
\hline 4 & $\begin{array}{l}5 \text { "diameter A-320 impeller. Initial agitator speed of 350 rpm and was increased to 500 } \\
\text { rpm during premix addition. Premix was added one minute and the entire batch was } \\
\text { mixed for an additional 30 seconds at 500 rpm. The walls of the drum were scraped } \\
\text { with a spatula. No lumps were present as the mix was poured. }\end{array}$ \\
\hline \hline
\end{tabular}

\subsection{Salt Solution and Premix Preparation}

Two different BSMR runs were performed. While a $0.63 \mathrm{w} / \mathrm{p}$ was targeted for both runs, a batching calculation error was made in determining the quantity of salt solution to combine with the premix for the first BSMR run. This resulted in w/p of 0.45 . For the second BSMR test, the $0.63 \mathrm{w} / \mathrm{p}$ was correctly used. The calculated properties of salt solution, water and premix for the two BSMR runs are provided in Table 2-6. The salt simulant composition used in the BSMR runs is shown in Table 2-3.

Table 2-6. Calculated Mass Fractions of Salt Solution and Premix in the BSMR Grouts

\begin{tabular}{|c|c|c|c|c|}
\hline \multicolumn{3}{|c|}{ Property } & $1^{\text {st }}$ Run & $2^{\text {nd }}$ Run \\
\hline \multirow{2}{*}{ Salt Solution } & \multicolumn{2}{|c|}{$\mathrm{Wt} \%$ Total Solids } & $27.99 \%$ & $27.99 \%$ \\
\hline & \multicolumn{2}{|c|}{ Density $(\mathrm{g} / \mathrm{mL})$} & 1.222 & 1.222 \\
\hline \multirow{4}{*}{$\begin{array}{c}\text { Premix } \\
\text { Densities }(\mathrm{g} / \mathrm{ml})\end{array}$} & \multicolumn{2}{|c|}{ Cement } & 3.14 & 3.14 \\
\hline & \multicolumn{2}{|c|}{ Fly Ash } & 2.26 & 2.26 \\
\hline & \multicolumn{2}{|c|}{ Slag } & 2.75 & 2.75 \\
\hline & \multicolumn{2}{|c|}{$\begin{array}{l}\text { Premix at blend } \\
\text { composition }\end{array}$} & 2.53 & 2.53 \\
\hline \multicolumn{3}{|c|}{$\mathrm{w} / \mathrm{p}$ ratio } & 0.454 & 0.63 \\
\hline \multirow{4}{*}{ Grout } & \multirow{3}{*}{$\begin{array}{l}\text { Mass } \\
\text { Fraction }\end{array}$} & Premix & 0.6135 & 0.5334 \\
\hline & & $\begin{array}{c}\text { Salt } \\
\text { Solution } \\
\end{array}$ & 0.3865 & 0.4666 \\
\hline & & Water & 0.2783 & 0.3360 \\
\hline & \multicolumn{2}{|c|}{ Density $(\mathrm{g} / \mathrm{mL})$} & 1.791 & 1.689 \\
\hline
\end{tabular}

\subsection{First BSMR Run 12/14/2010}

Two primary mixing tests were performed for collection of grout samples as the grout was pumped through the BSMR transfer line. The following physical properties from each run were obtained: rheology, flow cylinder, gel time, and density. 
The first mixing test was inadvertently conducted with a $\mathrm{w} / \mathrm{p}$ of 0.45 . This test provided limited information due to the low water to premix ratio of the pumped grout. Due to the thick nature of the grout produced, pumping and sampling of the grout was problematic. After 4:25 (min:sec) of operation, the indicated flow rate through from the pump discharge began to decrease. Steady state operation at the start of the test was 1.25 gpm flow and 90 psi pressure just beyond the pump exit. As the test progressed, the grout flow decreased and the back pressure increased above 90 psi. The initial attempt to collect a sample of the grout from the first sample valve was unsuccessful, as no grout would flow from the sample valve discharge. A grout sample was collected from the discharge at 7:25 elapsed time (ET). In an effort to maintain 1.25 gpm through the hose at 9:44 ET, the pump speed was increased from 50\% to 70\%. At 11:30 ET, another grout sample was collected from the hose discharge as the flow rate was $1.05 \mathrm{gpm}$ and the pressure had climbed to $>100$ psi. It was noted that the saltstone slurry in the feed tank appeared thicker than the initial batches had shown. Timing of the mixing operation had been managed to avoid having an inventory of grout slurry in the static feed tank at any time, with approximately 3 gallons batch being the target inventory level. It was noted the grout gave the appearance that the liquid seemed to separate from the slurry inventory and the grout in the tank appeared to be thickening. The grout inventory in the feed tank was agitated with a rod. Some small lumps of batch material could be "felt" in the batch inventory in the feed tank, but no plugs were ever detected in the tank discharge connection to the pump entry. Flow was maintained throughout the run, however the flow rate eventually decreased to as low as $0.67 \mathrm{gpm}$ just prior to the conclusion of the run. Samples were taken directly from the off-line mixing stations and from the static feed tank inventory. However samples could not be collected from the three sampling valves along the 300feet transfer line. At the conclusion of the first mixing test, fresh water was pumped through the BSMR for several minutes to clear the system of all residual grout.

\subsection{Second BSMR Run 1/14/2010}

The second run was performed with a w/p of 0.63 . Each prepared grout batch was deposited into the static feed tank such as to maintain a working inventory of grout for pumping through the BSMR at a continuous rate of 1.25 gallons per minute. Caution was taken to control the rate of grout production at the off-line mixing stations as to not create too large an inventory of grout in the static feed tank.

\subsection{Bench Scale Mixing Method Comparison}

As part of the mixing study for Saltstone, the effect of the paddle blade mixing method and the effect of the blender mixing method were compared and contrasted on various grout properties and related to the results obtained in the scale mixing tests. The grout properties evaluated included: volume $\%$ of bleed water, grout flow, yield stress, consistency, set time, fresh grout density, and gel time. For the bench scale mixing tests three salt solutions (Dissolution, Deliquification, and Adjustment (DDA), Modular Caustic Solvent Side Extraction Unit (MCU), and Salt Waste Processing Facility (SWPF) simulants were used to prepare grouts for comparison to the BMSR runs. For each mixing method/simulant combination, the grouts were mixed for approximately three minutes and the properties of interest were measured.

\subsection{Results and Discussion}

\subsection{First BSMR Run 12/14/2010 Results}

The activity log during the first BSMR run is provided in Table 3-1. The data shows that the flow rate decreases as the run persists, which is a function of the pumping capability and the 
SRNL-STI-2011-00346

Revision 0

rheological properties of the grout The data is indicative of changing rheological properties of the grout product, becoming more viscous as the test proceeds.

Table 3-1 First Mixing Test 12/14/2010 Activity Log

\begin{tabular}{|c|c|c|c||}
\hline $\begin{array}{c}\text { Run Time } \\
\text { Min : seconds }\end{array}$ & Activity & $\begin{array}{c}\text { Flow } \\
\text { (gpm) }\end{array}$ & $\begin{array}{c}\text { Pressure } \\
\text { (psi) }\end{array}$ \\
\hline $0: 00$ & $\begin{array}{r}\text { Transfer pump started - Start of mixing test } \\
\text { Sample A1 collected (Feed Sample) }\end{array}$ & $\mathrm{n} / \mathrm{a}$ & $\mathrm{n} / \mathrm{a}$ \\
\hline $4: 25$ & Grout product reaches discharge end of transfer hose & 1.23 & 90 \\
\hline $7: 25$ & Sample A2 collected from discharge end of transfer hose & 1.19 & 90 \\
\hline $9: 44$ & Steady state pump operation achieved at 70\% speed & 1.17 & $>100$ \\
\hline $11: 30$ & Sample A3 collected from discharge end of transfer hose & 1.05 & $>100$ \\
\hline $12: 33$ & Increased pump speed to 100\% & 1.06 & $>100$ \\
\hline $15: 23$ & Sample A4 collected from Static Feed Tank & $\mathrm{n} / \mathrm{a}$ & $\mathrm{n} / \mathrm{a}$ \\
\hline $22: 00$ & Marked flow decrease & 0.90 & $>100$ \\
\hline $23: 10$ & Sample A5 collected from discharge end of transfer hose & 0.89 & $>100$ \\
\hline $27: 15$ & Sample A6 collected from Static Feed Tank & 0.79 & $>100$ \\
\hline $33: 16$ & Sample A7 collected from discharge end of transfer hose & 0.82 & $>100$ \\
\hline $37: 00$ & Sample collected from discharge - no rheology analysis & 0.72 & $>100$ \\
\hline $38: 40$ & Sample A8 collected from discharge end of transfer hose & 0.67 & $>100$ \\
\hline
\end{tabular}

The physical properties and observations of the samples collected during processing are provided in Table 3-2 and Table 3-3 respectively. The discharge samples, A2, A3, and A5 show that shearing reduces the rheological properties as observed in both the Bingham Plastic and flow results as compared to the batch tank samples (A1 and A4), but these samples were becoming thicker as the run continued. Due to the reactive nature of this grout, having gel time less than 5 minutes, a feed tank sample was collected (A6) that shows gelling was occurring in the feed tank. The effect of this gelling directly impacts the grout in the transfer line, since the feed entering the transfer lines is rheologically thicker. The last two samples collected from the discharge line were more viscous than the previous sample and is due to both gel time effects and reduced shearing at the 5/8-inch ID tube walls due to reduction of flow rate. The changes in the rheological properties of this grout were affecting the ability of the pump to transfer the grout through the hose. It was also observed that the grout leaving the discharge of the hose had a visible central core region which was not sheared due to flow and this central core region is greater than what was calculated in section 2.1, due to it being more viscous than was used in section 2.1. Sampling the grout using the installed sample valves was not achievable. The visual observations in Table 3-3 also provide an indication of how the grout properties were changing throughout the test. The flow curves for the first BSMR run are provided in Appendix B. 
Table 3-2 First Mixing Test 12/14/2010 Physical Property Results

\begin{tabular}{|c|c|c|c|c|c|c|c|c|c|}
\hline \multirow{2}{*}{\multicolumn{2}{|c|}{ Sample Description }} & \multirow{3}{*}{$\begin{array}{c}\text { Run } \\
\text { Time } \\
\text { (min: } \\
\text { sec) }\end{array}$} & \multicolumn{4}{|c|}{ B Bingham Plastic } & \multirow{3}{*}{$\begin{array}{l}\text { Flow } \\
(\mathrm{cm})\end{array}$} & \multirow{3}{*}{$\begin{array}{c}\text { Density } \\
\text { (g/ml) }\end{array}$} & \multirow{3}{*}{$\begin{array}{c}\text { Gel } \\
\text { Time } \\
\text { (min) }\end{array}$} \\
\hline & & & \multirow{2}{*}{ Curve } & \multirow{2}{*}{$\begin{array}{l}\text { PV } \\
(\mathbf{c P})\end{array}$} & \multirow{2}{*}{$\begin{array}{l}\text { YS } \\
(\mathbf{P a})\end{array}$} & \multirow{2}{*}{$\begin{array}{c}\Delta \tau_{\max } \\
\text { shear rate } \\
\text { (Pa) }\end{array}$} & & & \\
\hline \# & Description & & & & & & & & \\
\hline \multirow{2}{*}{ A1 } & \multirow{2}{*}{ Batch Tank, Sample } & \multirow{2}{*}{ 00:00 } & $\mathrm{Up}$ & 258 & 42.7 & \multirow{2}{*}{7.5} & \multirow{2}{*}{13.3} & \multirow{2}{*}{1.85} & \multirow{2}{*}{$<5$} \\
\hline & & & Down & 271 & 24.1 & & & & \\
\hline \multirow{2}{*}{ A2 } & \multirow{2}{*}{ Discharge, Sample } & \multirow{2}{*}{$07: 25$} & Up & 69 & 13.0 & \multirow{2}{*}{1.1} & \multirow{2}{*}{22.2} & \multirow{2}{*}{1.78} & \multirow{2}{*}{$<5$} \\
\hline & & & down & 67 & 11.3 & & & & \\
\hline \multirow{2}{*}{ A3 } & \multirow{2}{*}{ Discharge, Sample } & \multirow{2}{*}{$11: 30$} & Up & 105 & 22.5 & \multirow{2}{*}{2.1} & \multirow{2}{*}{18.7} & \multirow{2}{*}{1.81} & \multirow{2}{*}{2.50} \\
\hline & & & down & 112 & 16.5 & & & & \\
\hline \multirow{2}{*}{ A4 } & \multirow{2}{*}{ Batch Tank, Sample } & \multirow{2}{*}{$15: 23$} & Up & 247 & 45.1 & \multirow{2}{*}{7.6} & 140 & 185 & 250 \\
\hline & & & down & 275 & 22.1 & & 14.9 & 1.85 & 2.50 \\
\hline$\Delta 5$ & Samnle & $23 \cdot 10$ & Up & 153 & 28.7 & & & & 0 \\
\hline AJ & Discharge, Sample & $23: 10$ & down & 159 & 21.8 & L.J & 10.2 & 1.92 & 1.00 \\
\hline$\Delta 6$ & Feed Tank Samnle & $27 \cdot 15$ & Up & 165 & 77.7 & 110 & 114 & $\mathrm{n} / \mathrm{m}$ & $\mathrm{n} / \mathrm{m}$ \\
\hline A6 & Feed I ank, sample & $2 /: 15$ & down & 285 & 23.3 & 11.9 & 11.4 & $\mathrm{n} / \mathrm{m}$ & $\mathrm{n} / \mathrm{m}$ \\
\hline A7 & & & $\mathrm{Up}$ & 189 & 34.2 & 29 & 143 & $\mathrm{n} / \mathrm{m}$ & $\mathrm{n} / \mathrm{m}$ \\
\hline A7 & Discharge, Sample & $33: 16$ & down & 197 & 26.1 & 2.9 & 14.3 & $\mathrm{n} / \mathrm{m}$ & $\mathrm{n} / \mathrm{m}$ \\
\hline$\Delta 8$ & Discharoe Samnle & $38 \cdot 40$ & $\mathrm{Up}$ & 181 & 43.6 & 46 & 140 & $\mathrm{n} / \mathrm{m}$ & $\mathrm{n} / \mathrm{m}$ \\
\hline Ao & Discriarge, sample & 50.40 & down & 204 & 28.2 & 4.0 & 14.0 & $11 / 111$ & $11 / 111$ \\
\hline
\end{tabular}

$\mathrm{PV}=$ Plastic Viscosity, YS $=$ Yield Stress, $\Delta \tau_{\text {max shear rate }}=$ Change in shear stress at maximum shear rate $\mathrm{n} / \mathrm{m}=$ not measured

Table 3-3 First Mixing Test 12/14/2010 Observations of Analyzed Samples

\begin{tabular}{||c|c||}
\hline \hline Sample \# & Notes/Observations \\
\hline A1 & Some clumps during pouring \\
\hline A2 & Lots of micro-bubbles present \\
\hline A3 & Lots of micro-bubbles present \\
\hline A4 & Looks like melted soft serve ice cream, not many air bubbles \\
\hline A5 & lots of micro-bubbles present, lots of clumps while pouring indicating early gel \\
\hline A6 & already gelling before pouring \\
\hline A7 & difficult to get a flat surface for measuring flow \\
\hline A8 & lots of clumping \\
\hline
\end{tabular}

\subsection{Second BSMR Run 1/14/2010 Results}

The activity log during the second BSMR run is provided in Table 3-4. The data shows that the flow rate during this run was maintained, but as the run proceeded, the pump discharge pressure increased. This increase in pump discharge pressure is due to the thickening or gelling of the grout product, and is reflected in the rheological properties of the grout provided in Table 3-5. 
SRNL-STI-2011-00346

Revision 0

Table 3-4 Second Mixing Test 1/14/2011 Activity Log

\begin{tabular}{|c|c|c|c||}
\hline $\begin{array}{c}\text { Time } \\
\text { (min:sec) }\end{array}$ & Activity & $\begin{array}{c}\text { Flow } \\
\text { (gpm) }\end{array}$ & $\begin{array}{c}\text { Pressure } \\
\text { (psi) }\end{array}$ \\
\hline $0: 00$ & Initial premix added to salt simulant at mixer - Start of \\
mixing test & $\mathrm{n} / \mathrm{a}$ & $\mathrm{n} / \mathrm{a}$ \\
\hline $1: 26$ & Sample B1 collected from first mixer pail (n/a) & $\mathrm{n} / \mathrm{a}$ & $\mathrm{n} / \mathrm{a}$ \\
\hline $2: 11$ & Transfer pump started & $\mathrm{n} / \mathrm{a}$ & $\mathrm{n} / \mathrm{a}$ \\
\hline $2: 41$ & Steady state pump operation achieved & 1.25 & 25 \\
\hline $6: 00$ & Sample collected from grout mix pail & 1.23 & 20 \\
\hline $8: 00$ & Sample B2 collected from Sample Valve \#1 & 1.27 & 40 \\
\hline $14: 00$ & Sample B3 collected from Sample Valve \#2 & 1.26 & 65 \\
\hline $20: 00$ & Sample B4 collected from Sample Valve \#3 & 1.26 & 68 \\
\hline $24: 35$ & Sample B5 collected from Static Feed Tank (n/a) & $\mathrm{n} / \mathrm{a}$ & $\mathrm{n} / \mathrm{a}$ \\
\hline $29: 00$ & Sample B6 collected from transfer hose discharge & 1.2 & 84 \\
\hline
\end{tabular}

The physical property results from the samples pulled during the second BSMR run are provided in Table 3-5. The applied shearing imparted on the grout by mixing in the batch tanks, as shown with sample B1, was adequate in removing a vast majority of the thixotropic property of the grout. In essence, additional shearing from the transfer line would have little effect in further reduction in rheological properties. The first sample pulled, B1, seems to indicate that the Moyno pump may be providing more shearing than expected. As with the first BSMR run, the effect of gel time or static mixing time was observed as the run proceeded and this is evident with the increase in both the rheological properties and flow measurements as well as the steady increase in discharge pressure throughout this run as observed in Table 3-4. Sample B5 from the feed tank was obtained towards the end of the run to compare the results with the final discharge sample and to determine if gelling was impacting the feed going into the transfer pump and transfer line. The effect of gel is obvious on this sample when compared to all the other samples in Table 3-5, the sample was rheologically much thicker. The difference can be observed in the flow curves in Appendix C, see Figure C-5. The final sample analyzed was the discharge sample with a plastic viscosity of $78.9 \mathrm{cP}(\mathrm{B} 6)$. The rheological properties of the discharge sample were comparable to the feed tank sample which had a plastic viscosity of $79.7 \mathrm{cP}$ (B5). It was expected that the tank contents that provided the B6 sample would have been rheologically thicker than those measured in sample B5, since an additional 5 minutes and 25 seconds of time had passed and the measured gel time of each sample was $<5$ minutes. Visual observation of the discharge stream did not show the same type of clumping that was observed in the first BSMR run and can be contributed to the difference in the rheological properties of the two runs and w/p ratios. Appendix $C$ contains the flow curves for the second BSMR run. 
Table 3-5 Second Mixing Test 1/14/2011 Physical Property Results

\begin{tabular}{|c|c|c|c|c|c|c|c|c|c|}
\hline \multirow{2}{*}{\multicolumn{2}{|c|}{ Sample Description }} & \multirow{3}{*}{$\begin{array}{c}\text { Run } \\
\text { Time } \\
\text { (min: } \\
\text { sec) }\end{array}$} & \multicolumn{4}{|c|}{ Bingham Plastic } & \multirow{3}{*}{$\begin{array}{l}\text { Flow } \\
\text { (cm) }\end{array}$} & \multirow{3}{*}{$\begin{array}{l}\text { Density } \\
(\mathrm{g} / \mathrm{ml})\end{array}$} & \multirow{3}{*}{$\begin{array}{c}\text { Gel } \\
\text { Time } \\
\text { (min) }\end{array}$} \\
\hline & & & \multirow{2}{*}{ Curve } & \multirow{2}{*}{$\begin{array}{l}\text { PV } \\
\text { (cP) }\end{array}$} & \multirow{2}{*}{$\begin{array}{c}\text { YS } \\
\text { (Pa) }\end{array}$} & \multirow{2}{*}{$\begin{array}{c}\Delta \tau_{\max } \\
\text { shear rate } \\
\text { (Pa) }\end{array}$} & & & \\
\hline$\#$ & Description & & & & & & & & \\
\hline \multirow{2}{*}{ B1 } & \multirow{2}{*}{ Batch Tank } & \multirow{2}{*}{$1: 26$} & Up & 62.5 & 5.0 & \multirow{2}{*}{0.38} & \multirow{2}{*}{21.5} & \multirow{2}{*}{1.68} & \multirow{2}{*}{$<5$} \\
\hline & & & Down & 57.1 & 5.7 & & & & \\
\hline \multirow{2}{*}{$\mathrm{B} 2$} & \multirow{2}{*}{ Valve 1} & \multirow{2}{*}{ 8:00 } & $\mathrm{Up}$ & 67.4 & 4.5 & \multirow{2}{*}{0.15} & \multirow{2}{*}{23.6} & \multirow{2}{*}{1.68} & \multirow{2}{*}{$<5$} \\
\hline & & & down & 64.6 & 4.8 & & & & \\
\hline \multirow{2}{*}{ B3 } & \multirow{2}{*}{ Valve 2} & \multirow{2}{*}{$14: 00$} & $\mathrm{Up}$ & 68.8 & 7.6 & \multirow{2}{*}{1.08} & \multirow{2}{*}{22.4} & \multirow{2}{*}{1.66} & \multirow{2}{*}{$<5$} \\
\hline & & & down & 65.4 & 6.4 & & & & \\
\hline \multirow{2}{*}{ B4 } & \multirow{2}{*}{ Valve 3} & \multirow{2}{*}{$20: 00$} & Up & 69.4 & 7.1 & \multirow{2}{*}{0.69} & \multirow{2}{*}{21.7} & \multirow{2}{*}{1.66} & $<5$ \\
\hline & & & down & 65.9 & 6.7 & & & & \\
\hline B5 & Feed Tank & $24 \cdot 35$ & Up & 92.1 & 16.6 & 307 & $\mathrm{n} / \mathrm{n}$ & $\mathrm{n} / \mathrm{n}$ & $\mathrm{n} / \mathrm{m}$ \\
\hline & геed I dink & $24.5 J$ & down & 78.9 & 6.3 & 0.07 & $\mathrm{n} / \mathrm{m}$ & $\mathrm{n} / \mathrm{m}$ & $\mathrm{n} / \mathrm{m}$ \\
\hline B6 & Discharoe & $20 \cdot 02$ & $\mathrm{Up}$ & 83.8 & 10.2 & 107 & 208 & 164 & $<5$ \\
\hline & Discharge & & down & 79.7 & 7.5 & & & & \\
\hline
\end{tabular}

$\mathrm{PV}=$ Plastic Viscosity, YS $=$ Yield Stress, $\Delta \tau_{\text {max shear rate }}=$ Change in shear stress at maximum shear rate $\mathrm{n} / \mathrm{m}=$ not measured

\section{$\underline{3.3}$ Bench Scale Mixing Method Comparison}

An indication of the difference in mixing can be seen in the photographs of the flow tests, Figure 3-1. The sample mixed with the blender disengaged the coal associated with the fly as h allowing it to float, whereas the paddle blade incorporated the coal resulting in a more uniform sample. This was observed in each of the three simulants.
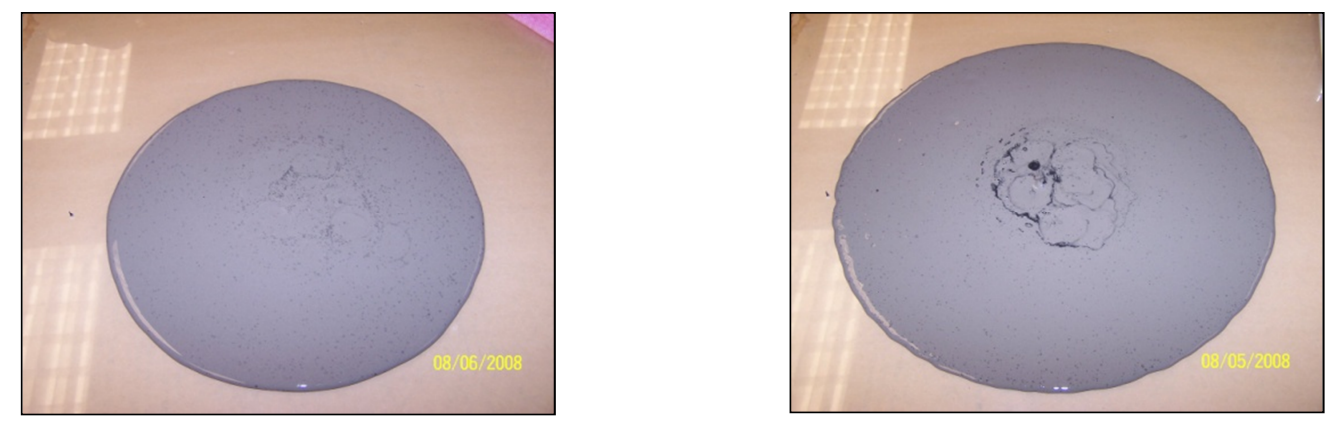

Figure 3-1. Grout flow results of DDA simulant with paddle blade and blender

\subsubsection{SWPF}

Neither the blender mix nor the paddle blade mix produced bleed water. The grout flow proved to be greatly affected by the mixing technique used. The paddle blade mix had a grout flow of 21.6 $\mathrm{cm}$, whereas the blender mix had a grout flow of $25.8 \mathrm{~cm}$. The rheology of the two mixing methods concluded that the consistency of the paddle blade is two times greater than that of the blender, although the yield stress was about the same. The set resulted in the 1-day paddle blade mix having $4 \mathrm{~mm}$ and the blender mix having $14 \mathrm{~mm}$. Both methods resulted in complete set at 0 $\mathrm{mm}$ on the second day. The density of the blender mix was $1.70 \mathrm{~g} / \mathrm{mL}$, lower than that of the paddle blade mix density of $1.70 \mathrm{~g} / \mathrm{mL}$. The gel time between the paddle blade mix and the blender mix was 90 and 30 minutes, respectively. 


\subsubsection{DDA}

Both the blender and the paddle blade mixed grouts had significant amounts of bleed water after one day. As seen with the SWPF simulant, there was a difference between the grout flows of the two mixing methods. The paddle blade mix had a grout flow of about $24.9 \mathrm{~cm}$, whereas the blender mix had a grout flow of about 30.8, similar to the results obtained for the SWPF simulant. The paddle blade mix had both greater consistency and yield stress than that of the blender mix. The set times also were very different with the DDA blender mix having $50 \mathrm{~mm}$ and the DDA paddle blade mix having $35 \mathrm{~mm}$ on the 1-day set. Both mix methods were completely set with a measurement of $0 \mathrm{~mm}$ on the second day. The density of the paddle blade mix, at $1.67 \mathrm{~g} / \mathrm{mL}$, was slightly higher than that of the blender mix, at $1.65 \mathrm{~g} / \mathrm{mL}$. The gel times of both the DDA paddle blade mix and the DDA blender mix were greater than three hours.

\subsubsection{MCU}

Saltstone made with both mixing methods showed no signs of bleed water. Grout flows of the paddle blade mix, at $21.9 \mathrm{~cm}$, and the blender mix, $24.4 \mathrm{~cm}$, were similar. The consistency of the paddle blade was almost three times that of the blender. Also, the yield stress of the paddle blade was about two times greater than that of the blender. The blender mix had a slightly higher 1-day set at $2 \mathrm{~mm}$ when compared to the $1 \mathrm{~mm}$ set of the paddle blade mix. Both mix methods were completely set with a measurement of $0 \mathrm{~mm}$ on the second day. The blender mix had a lower density, at $1.68 \mathrm{~g} / \mathrm{mL}$, than the paddle blade mix, which had a density of $1.73 \mathrm{~g} / \mathrm{mL}$. The gel time of the blender was 10 minutes, while the paddle blade gel time was 30 minutes.

\subsection{Relating Bench Scale Mixing to BMSR Testing}

Results of the testing with the three simulants are shown in Table 3-6. The properties of the bench scale mixing in Table 2-4 for the sample mixed for three minutes and the sample taken from the second BMSR run after 14 minutes of operation, B3, are included for comparison. The salt solution/mix method that most closely resembles the consistency, yield stress, and flow of the paddle blade mixing of the salt solution used for the BMSR is the paddle blade mixing of the MCU simulant. These bench scale mixing conditions are both similar to the sample collected after 14 minutes of operation during the second BMSR run. 
Table 3-6 Properties of Salt Simulants Mixed by Different Methods.

\begin{tabular}{|c|c|c|c|c|c|c|c|c|c|c|}
\hline \multirow{2}{*}{\multicolumn{2}{|c|}{ Sample Description }} & \multicolumn{4}{|c|}{ Bingham Plastic } & \multirow{3}{*}{$\begin{array}{l}\text { Flow } \\
\text { (cm) }\end{array}$} & \multirow{3}{*}{$\begin{array}{c}\text { Density } \\
(\mathrm{g} / \mathrm{ml})\end{array}$} & \multirow{3}{*}{$\begin{array}{c}\text { Gel } \\
\text { Time } \\
\text { (min) }\end{array}$} & \multirow{2}{*}{\multicolumn{2}{|c|}{$\begin{array}{l}\text { Bleed } \\
(\text { vol\%) }\end{array}$}} \\
\hline & & \multirow[b]{2}{*}{ Curve } & \multirow{2}{*}{$\begin{array}{l}\text { PV } \\
\text { (cP) }\end{array}$} & \multirow{2}{*}{$\begin{array}{l}\text { YS } \\
\text { (Pa) }\end{array}$} & \multirow{2}{*}{$\begin{array}{c}\Delta \tau_{\max } \\
\text { shear rate } \\
(\mathbf{P a})\end{array}$} & & & & & \\
\hline Salt & $\begin{array}{l}\text { Mixing } \\
\text { Method }\end{array}$ & & & & & & & & 1d & 2d \\
\hline \multirow{4}{*}{ SWPF } & \multirow{2}{*}{ Paddle } & $\mathrm{Up}$ & 85.1 & 6.1 & \multirow{2}{*}{0.70} & \multirow{2}{*}{21.6} & \multirow{2}{*}{1.70} & \multirow{2}{*}{90} & \multirow{2}{*}{0} & \multirow{2}{*}{0} \\
\hline & & Down & 87.4 & 3.8 & & & & & & \\
\hline & \multirow{2}{*}{ Blender } & Up & 37.2 & 6.7 & \multirow{2}{*}{0.15} & \multirow{2}{*}{25.8} & \multirow{2}{*}{1.70} & \multirow{2}{*}{30} & \multirow{2}{*}{0} & \multirow{2}{*}{0} \\
\hline & & down & 43.1 & 4.7 & & & & & & \\
\hline \multirow{4}{*}{ DDA } & \multirow{2}{*}{ Paddle } & up & 51.1 & 5.4 & \multirow{2}{*}{0.23} & \multirow{2}{*}{24.9} & \multirow{2}{*}{1.67} & \multirow{2}{*}{$>180$} & \multirow{2}{*}{6.8} & \multirow{2}{*}{6.4} \\
\hline & & down & 55.3 & 3.8 & & & & & & \\
\hline & \multirow{2}{*}{ Blender } & up & 17.7 & 3.0 & 025 & 308 & 164 & $>180$ & 55 & 52 \\
\hline & & down & 18.8 & 2.7 & $0.2 J$ & 50.0 & 1.64 & $>180$ & 5.5 & 5.2 \\
\hline & Paddle & up & 96.2 & 8.8 & 083 & 244 & 168 & 10 & 0 & 0 \\
\hline MCU & & down & 103.2 & 5.0 & & & & & & \\
\hline & Blender & up & 32.6 & 6.3 & 0.10 & 210 & 173 & 30 & 0 & 0 \\
\hline & Blender & down & 36.3 & 5.1 & 0.10 & 21.9 & 1.73 & 30 & 0 & 0 \\
\hline Cell E & Paddle & up & 67.3 & 4.7 & -8, & 8 & NM & $<7$ & NM & NM \\
\hline $180 \mathrm{~s}$ & Padale & down & 60.1 & 6.8 & $-c$ & 8 & NIM & & & \\
\hline Valve & Paddlo & up & 68.8 & 7.6 & 108 & 224 & 166 & $<5$ & NM & NM \\
\hline 2 & Paddle & down & 65.4 & 6.4 & 1.08 & 22.4 & 1.66 & $<5$ & NM & NMI \\
\hline
\end{tabular}

\subsection{Conclusions}

Scaling between the full scale piping at Saltstone to bench scale testing at SRNL was performed by maintaining the same shear rate and total shear at the wall of the transfer line. The results of scaling down resulted in a shorter transfer line, a lower average velocity, the same transfer time and similar pressure drops. The condition of flow in the bench scale is highly laminar as were the flow in the full scale pipe is in the transition region, but is more laminar than turbulent. The resulting plug in laminar flow in the bench scale results in a region of no-mixing. Hence mixing, or shearing, at the bench scale should be less than that observed in the full scale, where this plug is non existent due to the turbulent flow. The bench scale tests should be conservative due to the highly laminar condition of flow that exists. Additionally, calculations were performed to determine the shearing contribution from the Moyno pump and it is expected that the shearing from this pump to be negligible as compared to that provided by the walls of the transfer line.

The selected grout simulant used for testing was shown to be thixotropic. Given adequate mixing times and agitator speed using conventional mixers, the thixotropic properties are removed. This grout was also shown to have gel properties that given the time scale of bench scale tests, could impact the results due to changing rheological properties. As grout gels, the rheological properties increase.

Two BSMR runs were performed, at w/p ratios of 0.45 and 0.63 . In both cases, wall shearing was shown to reduce the rheological properties of the grout as it was processed through the transfer line. Samples taken at the static feed tank showed that gelling impacted the rheological properties of the grout before it was fed into the pump and transfer line. This was observed in the first test, where the flow rate through the transfer line decreased though out the run and the rheological properties from the discharge of the transfer line increased throughout. A sample from the static 
feed tank indicated that gelling of the grout was a factor causing this reduction in flow, and that shearing of the grout during transfer through the BSMR was making the grout more fluid. The shearing by the BSMR was not, however, sufficient to reduce the gelling properties of the grout.

In the second BSMR run, gelling of the grout was again clearly a factor and was evident by the increase in the pressure drop in the transfer line while the average flow velocity was maintained constant. Rheological measurements of the grout samples taken throughout the BSMR also indicated gelling of the grout with time. Excessive mixing in preparing the grout in the batch tank for the second run reduced the expected thixotropic behavior. A comparison of the rheological properties of samples taken at the feed tank and transfer line discharge indicated shearing of the grout was occurring in the transfer line. The data also suggests that there was more shearing by the transfer pump, given that the rheology of samples taken downstream of the transfer pump was slightly less than that of samples taken directly from the feed tank.

Bench scale testing of different mixing methods with three different salt solutions showed that method of mixing influences the rheological properties of the grouts. The paddle blade mixing method of the salt solution used for the BMSR testing provided comparable rheological properties of the grout prepared in the BMSR after 14 minutes of processing, B3. The paddle blade mixing method can be used to represent BMSR results and mixing time can be adjusted to represent larger scale mixing.

\subsection{References}

${ }^{1}$ Spires, R.H., "Strategy for Saltstone Product Quality Assurance," LWO-SPT-2008-00031, March 2008.

${ }^{2}$ Staub, A.V., Technical Task Request, HLW-SSF-TTR-2009-0003, Savannah River Site, Aiken, SC, Nov. 2008.

${ }^{3}$ Pickenheim, B.R. and Cozzi, A.D., "Task Technical \& Quality Assurance Plan for Bench Scale Saltstone Process Development”, SRNL-TR-2009-00133, Savannah River National Laboratory, Aiken, SC, May 2010.

4 "Saltstone Facility System Design Description (U) Saltstone Process," G-SD-Z-00003, Revision 0 .

${ }^{5}$ Hansen, E.K., and Langton, C.A., Physical Characterization of FY2004 Saltstone Simulant Slurries, WSRC-TR-2005-00365, Rev. 0, August 2005

${ }^{6}$ Abulnaga, B., Slurry Systems Handbook. New York: McGraw-Hill, 2002

${ }^{7}$ Darby, R., Chemical Engineering Fluid Mechanics. Second edition, New York: Marcel Dekker, 2001.

${ }^{8}$ Heywood, N.I. and Brown, N.P, Slurry Handling Design of Solid-Liquid Systems, London: Elsevier Applied Science, 1991

${ }^{9}$ Wasp, E.J., Kenny, J.P., and Gandhi, R.L., Solid-Liquid Flow Slurry Pipeline Transportation, Series on Bulk Material Handling Vol. 1, No. 4, Trans Tech Publications, 1977

${ }^{10}$ Karassik, I.J., Krutzsch, W.C., Fraser, W.H., and Messina, J.P., Pump Handbook, Second edition, McGraw-Hill Book Company, 1976

${ }^{11}$ Bird, R.B., Stewart, W.E, and Lightfoot, E.N., Transport Phenomena, Second edition, John Wiley \& Sons, Inc., 2002 
SRNL-STI-2011-00346

Revision 0

Appendix A - Flow Curves from Conventional Mixing Test 


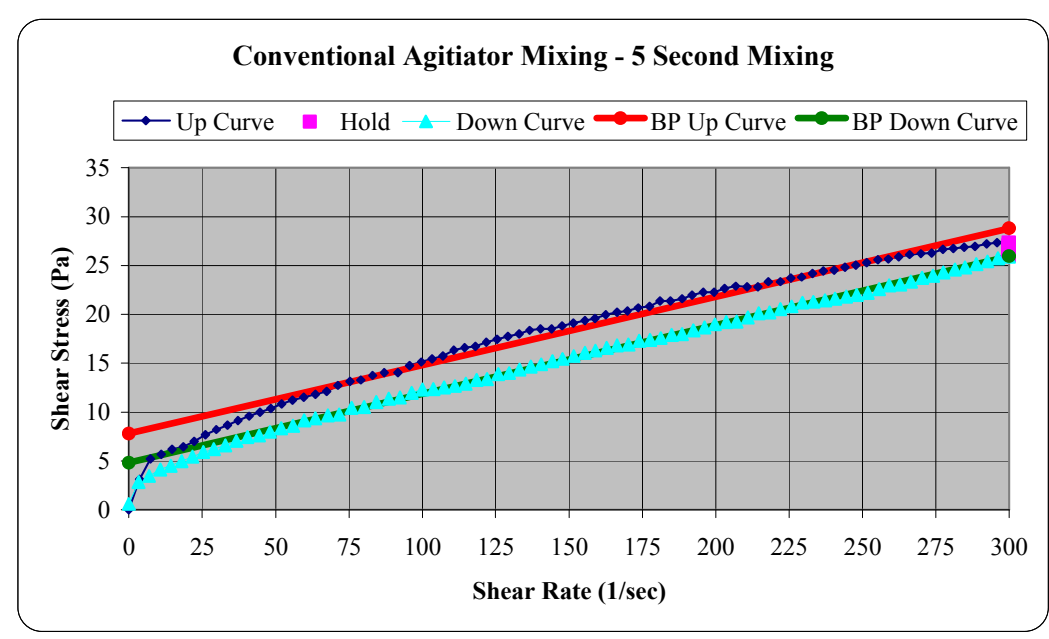

Figure A - 1 Conventional Mixing - 5 seconds

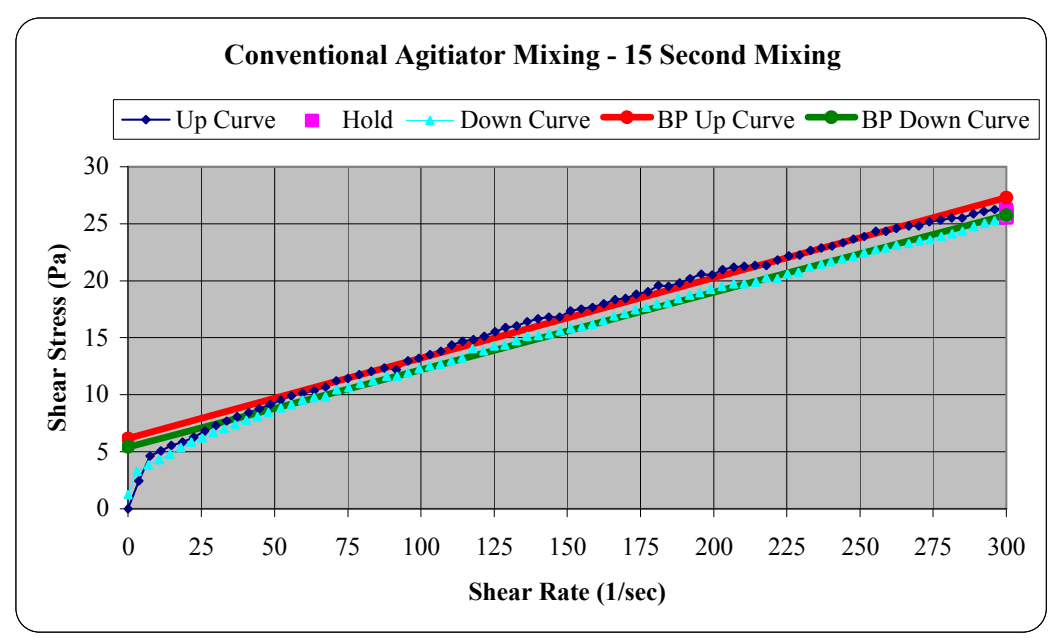

Figure A - 3 Conventional Mixing - 15 seconds

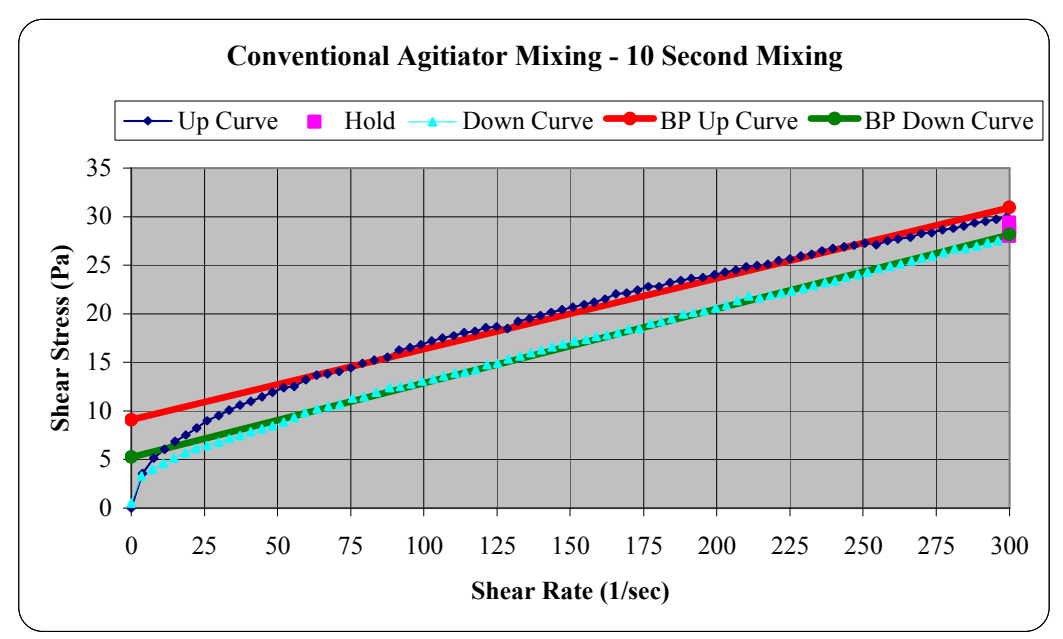

Figure A - 2 Conventional Mixing - 10 seconds

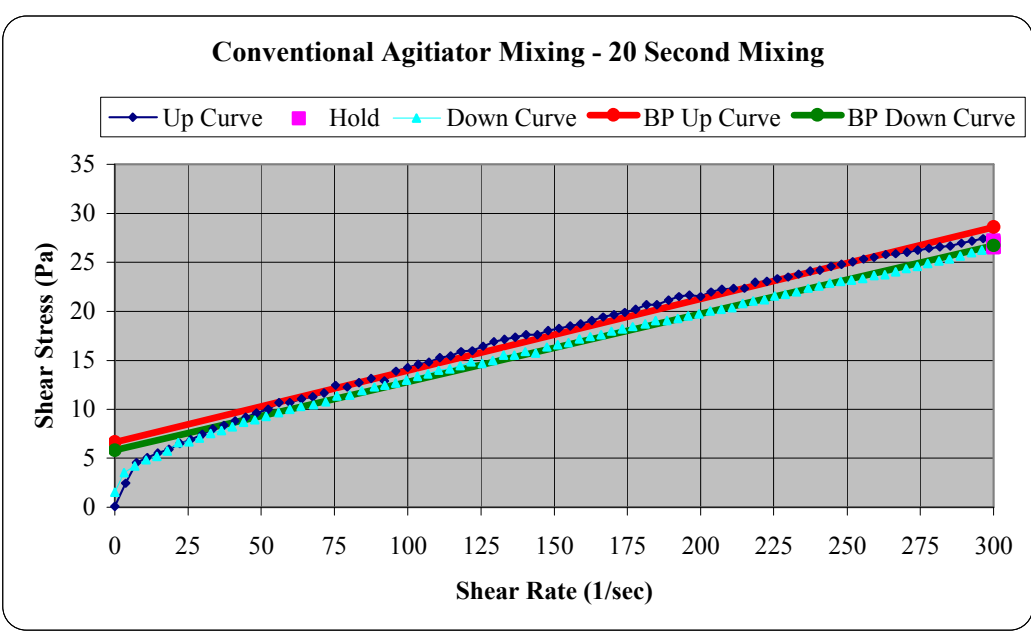

Figure A - 4 Conventional Mixing - 20 seconds 


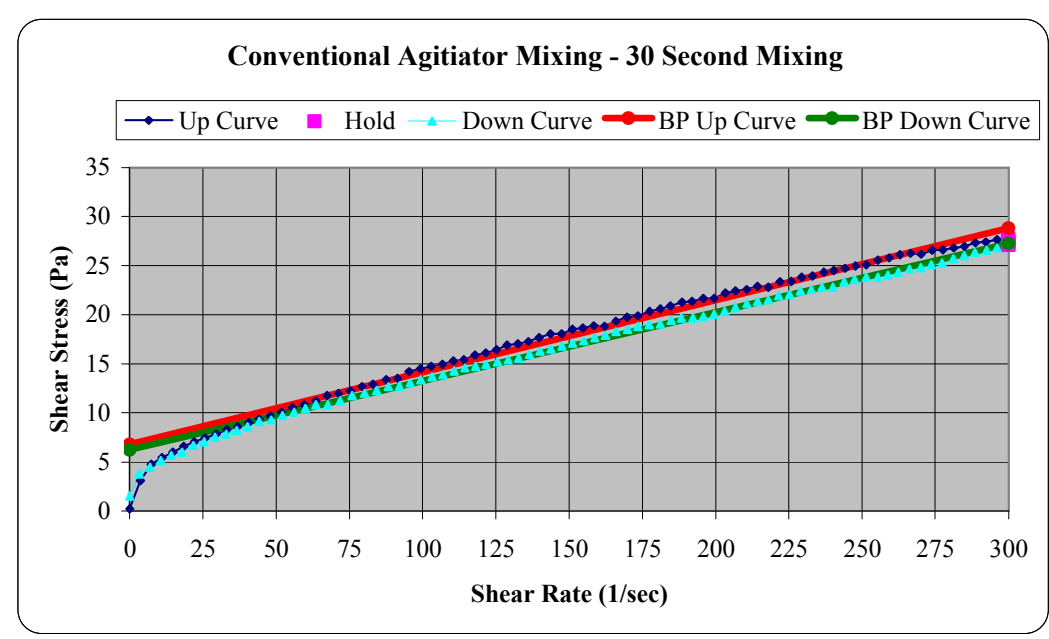

Figure A - 5 Conventional Mixing - 30 seconds

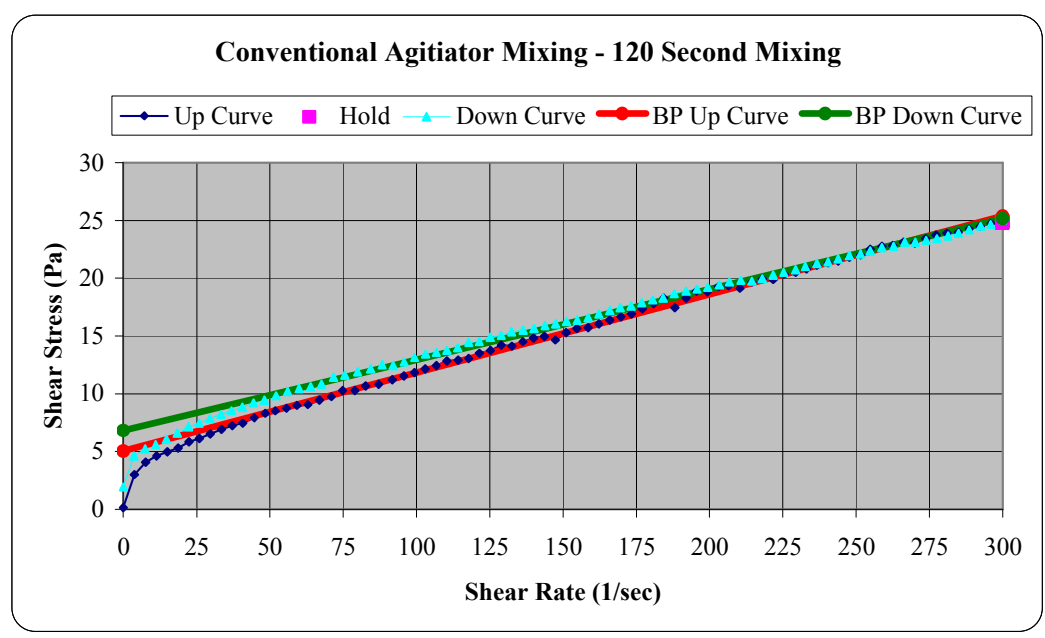

Figure A - 7 Conventional Mixing - 120 seconds

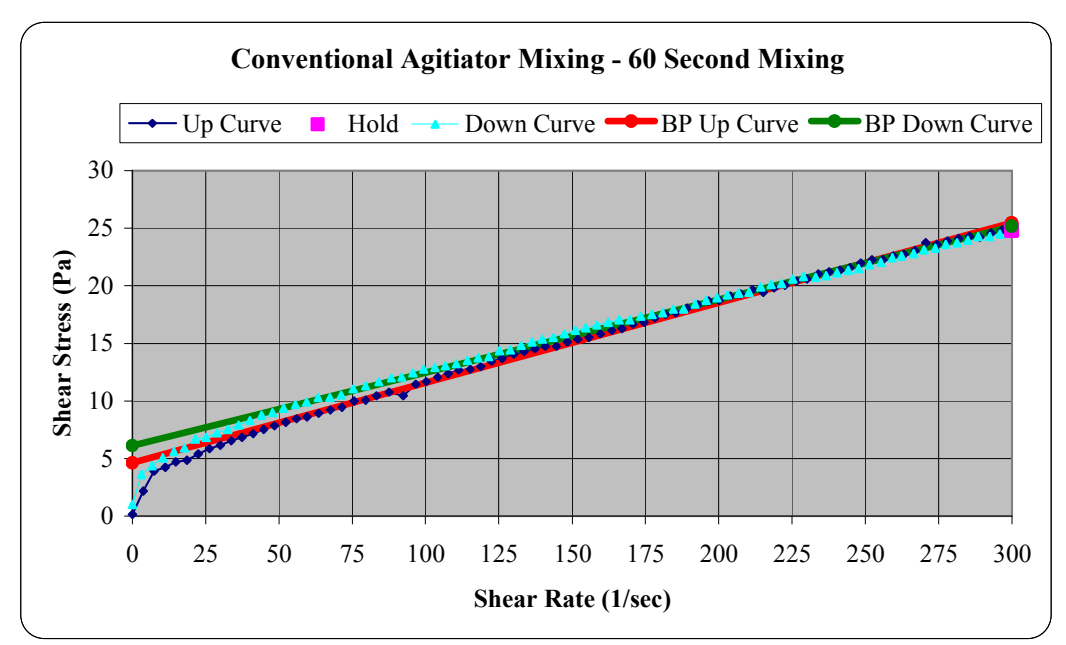

Figure A - 6 Conventional Mixing - 60 seconds

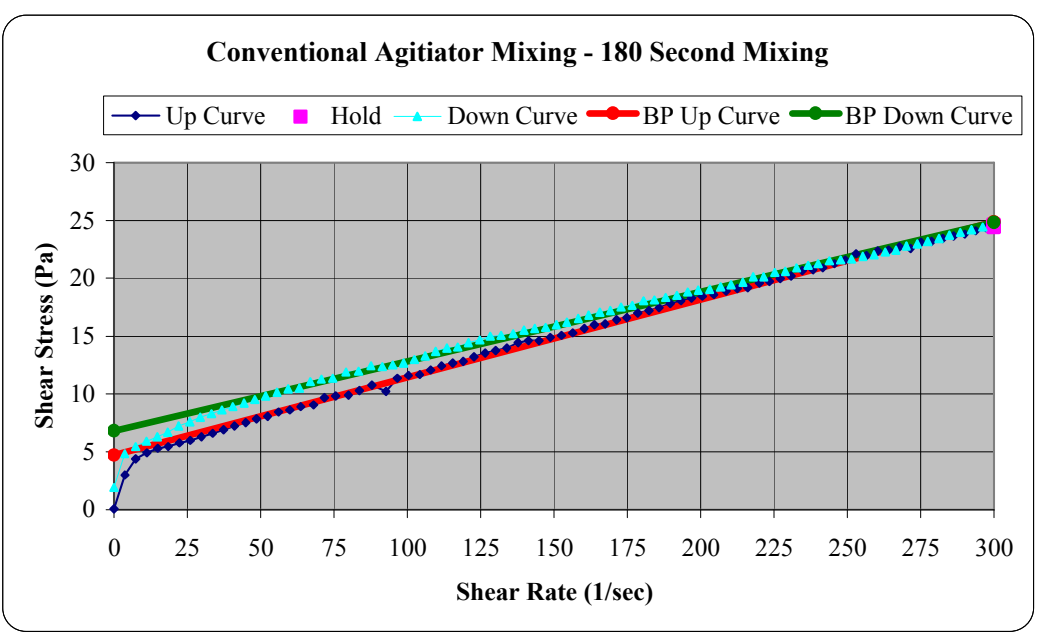

Figure A - 8 Conventional Mixing - 180 seconds 


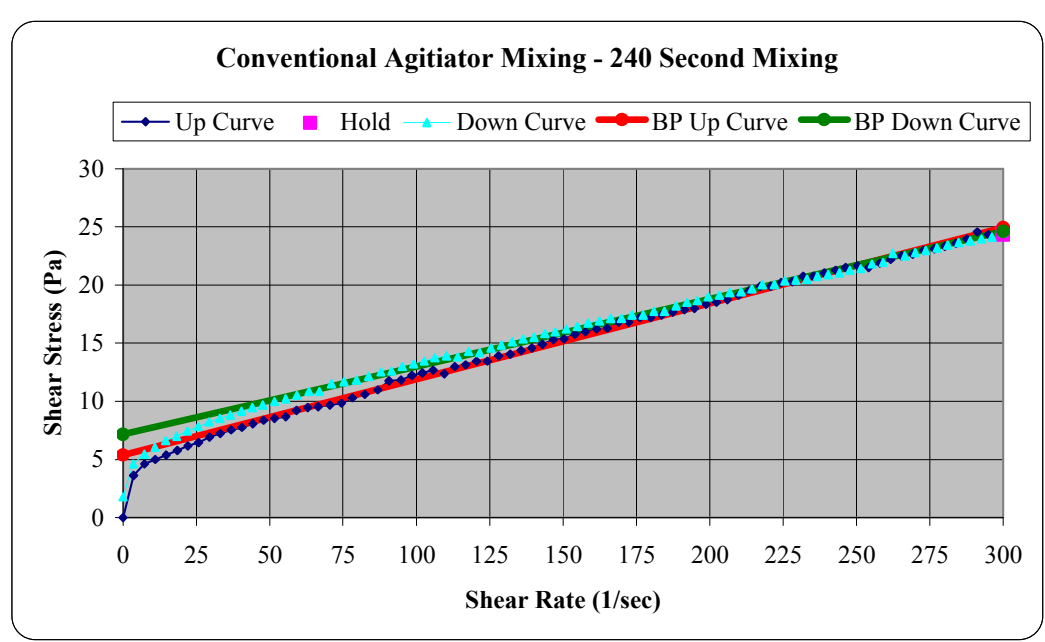

Figure A - 9 Conventional Mixing - 240 seconds

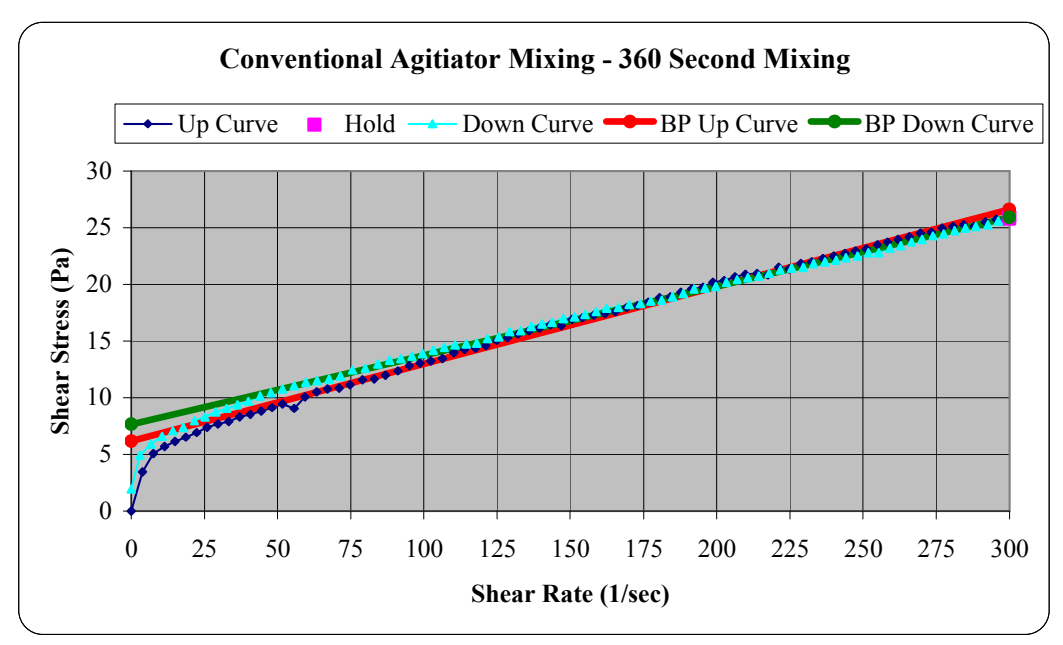

Figure A - 10 Conventional Mixing - 360 seconds 
Appendix B - Flow Curves from First BSMR Run 


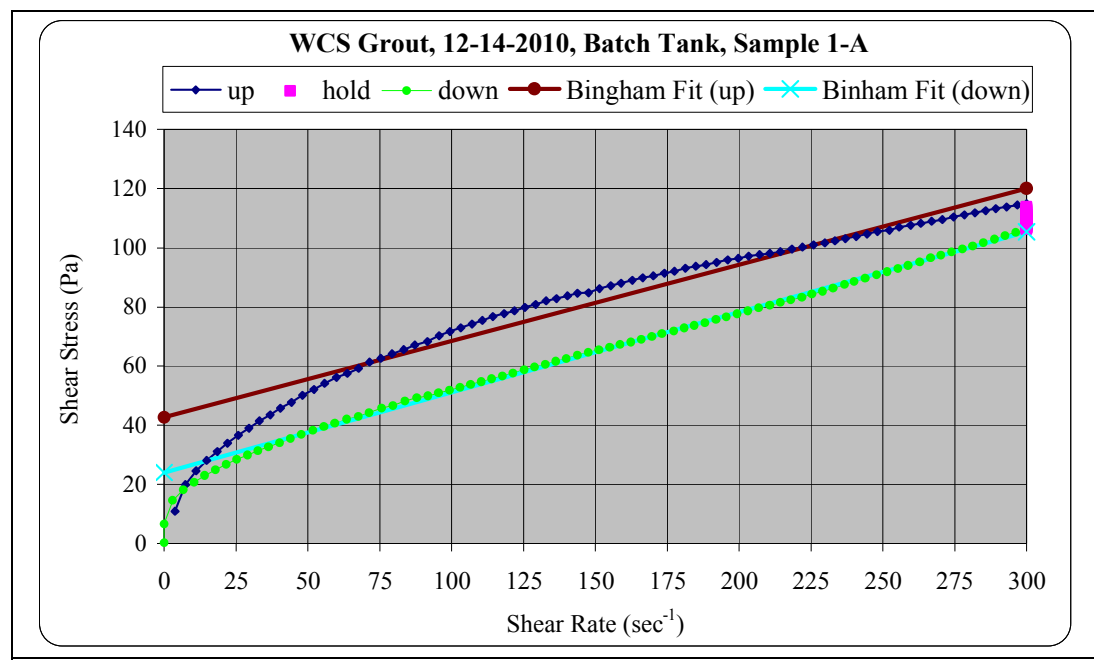

Figure B - 1 BSMR Run 1 - Batch Tank, Sample 1-A

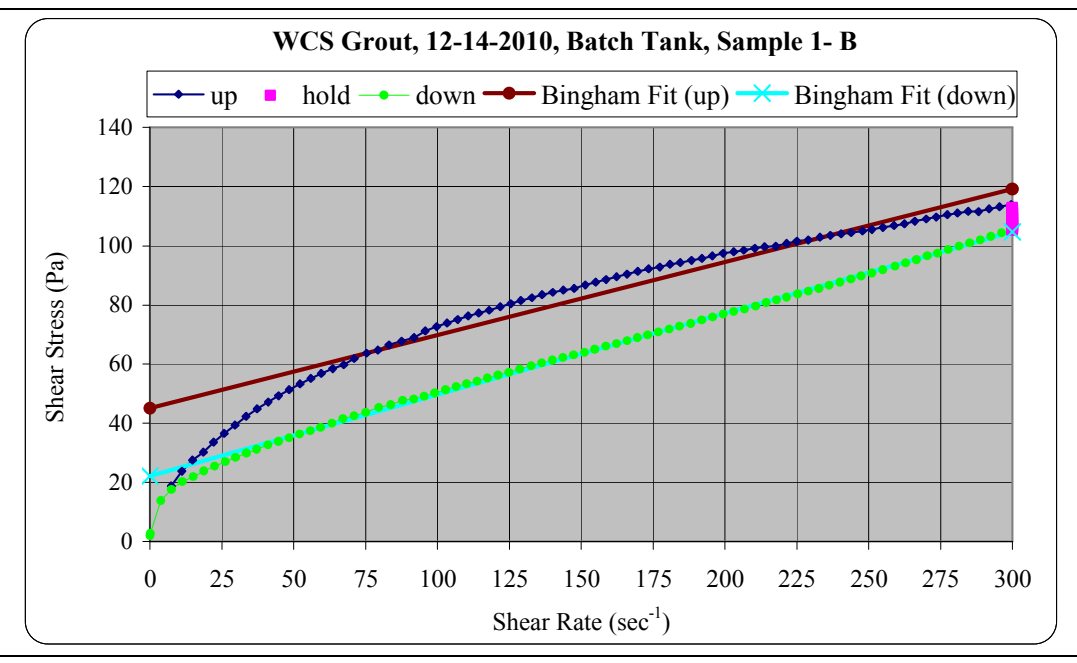

Figure B - 2 BSMR Run 1 - Batch Tank, Sample 1-B

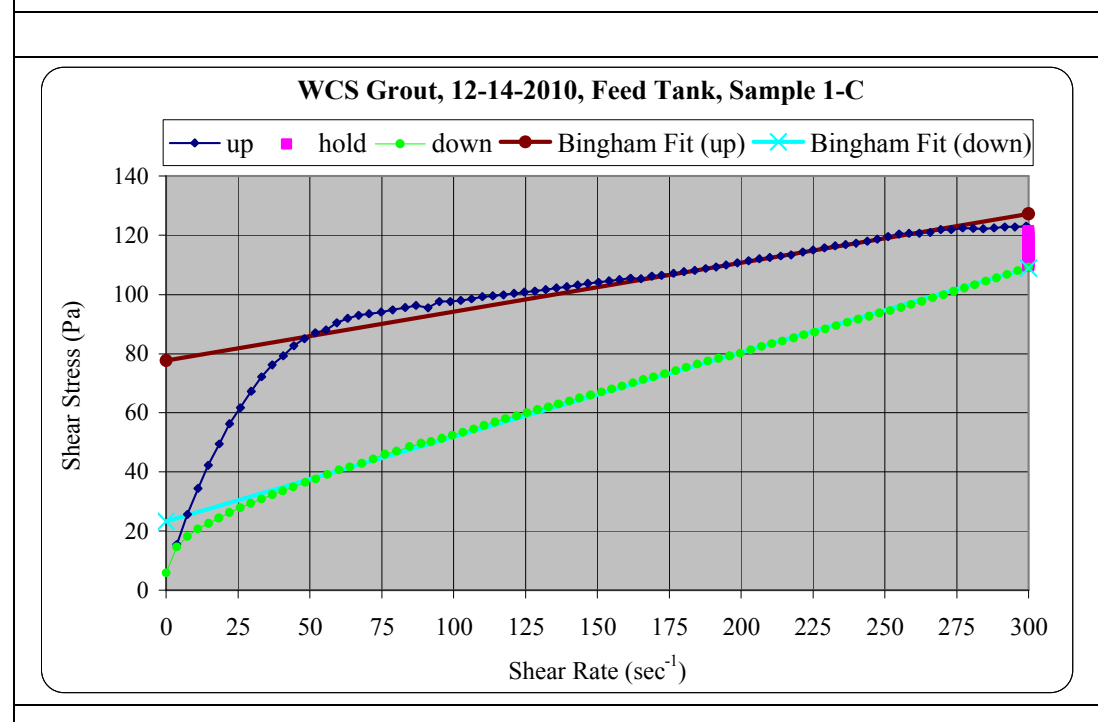

Figure B - 3 BSMR Run 1 - Feed Tank, Sample 1-C

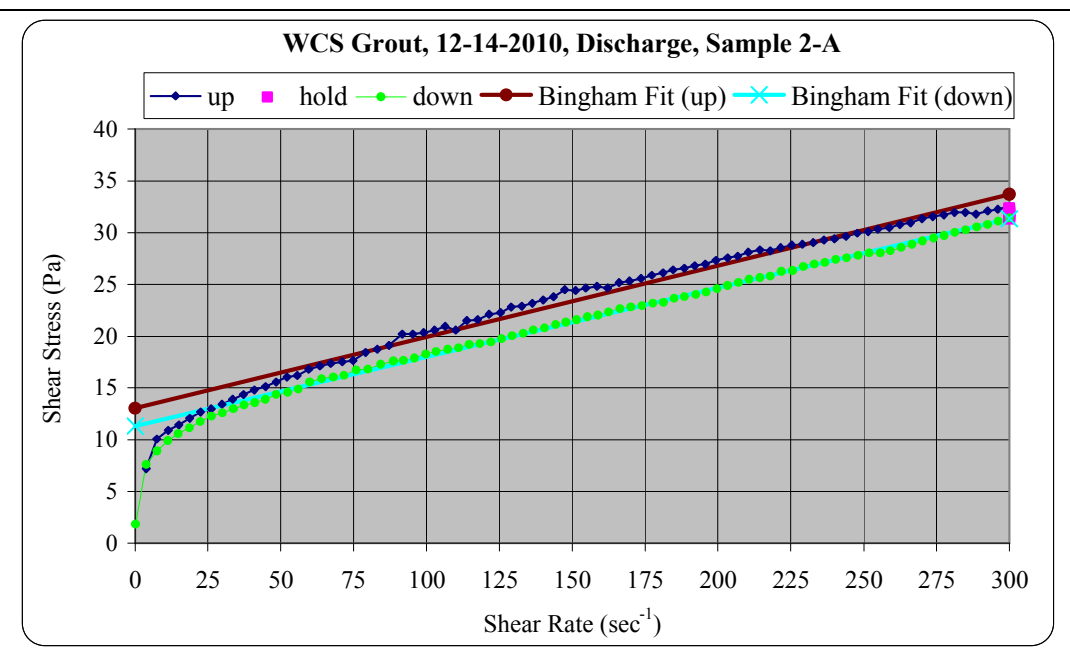

Figure B - 4 BSMR Run 1 - Discharge, Sample 2-A 


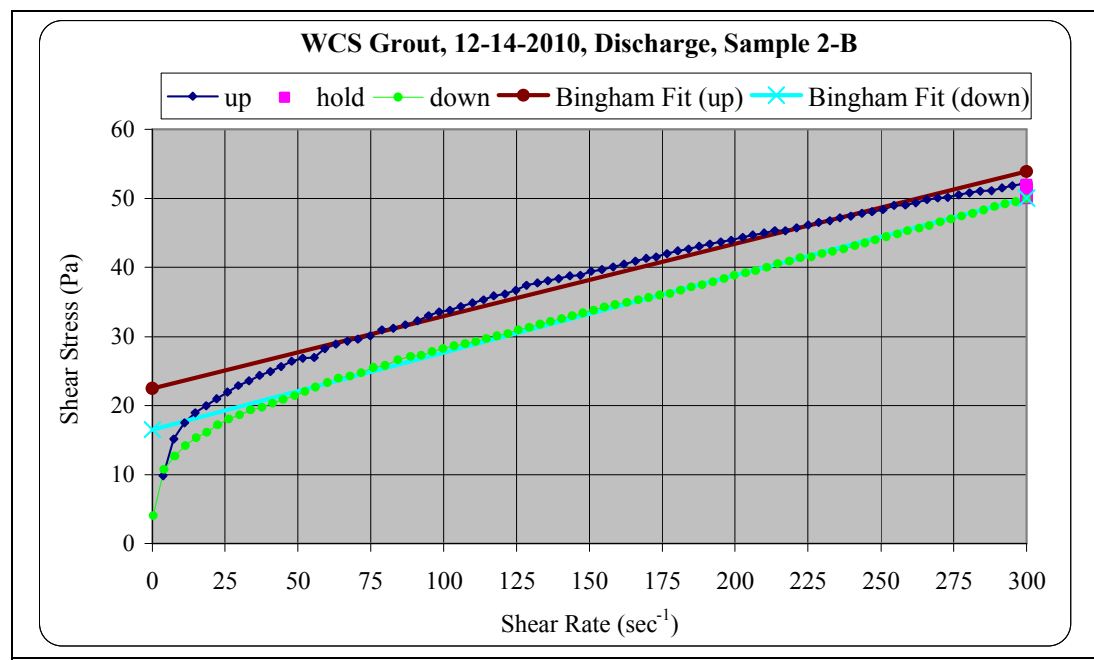

Figure B - 5 BSMR Run 1 - Discharge, Sample 2-B

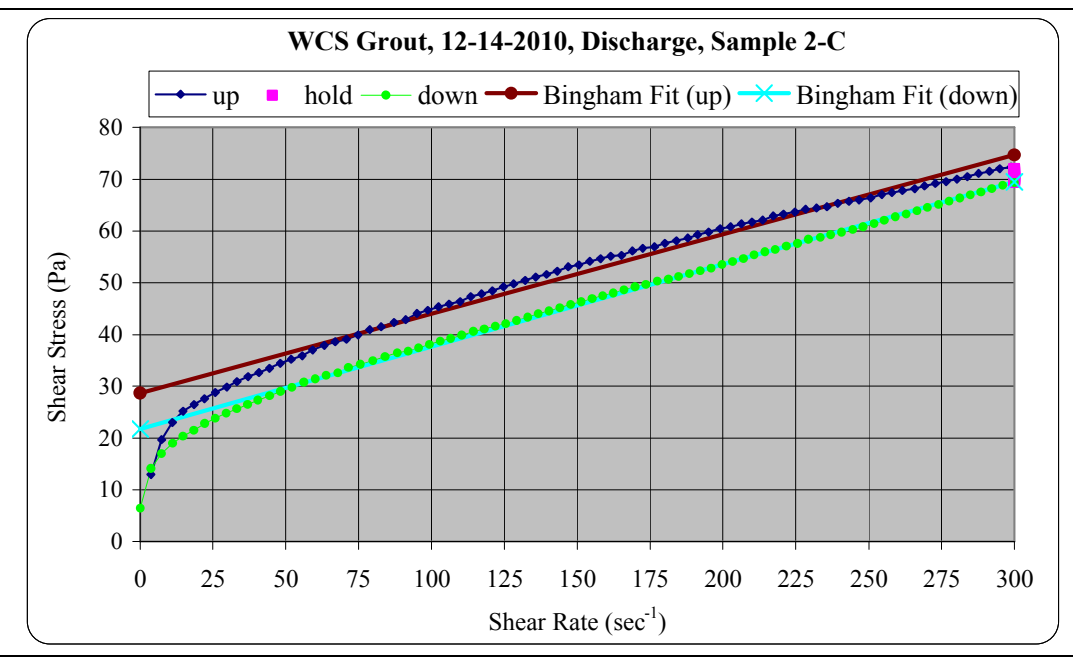

Figure B - 6 BSMR Run 1 - Discharge, Sample 2-C

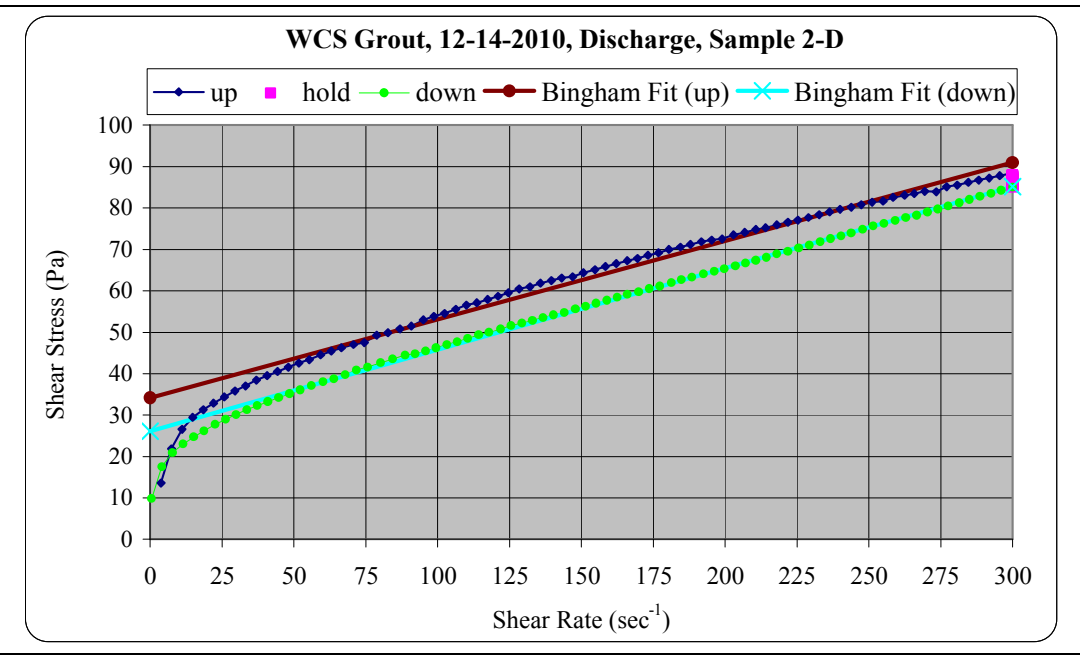

Figure B - 7 BSMR Run 1 - Discharge, Sample 2-D

\section{WCS Grout, 12-14-2010, Discharge, Sample 2-E}

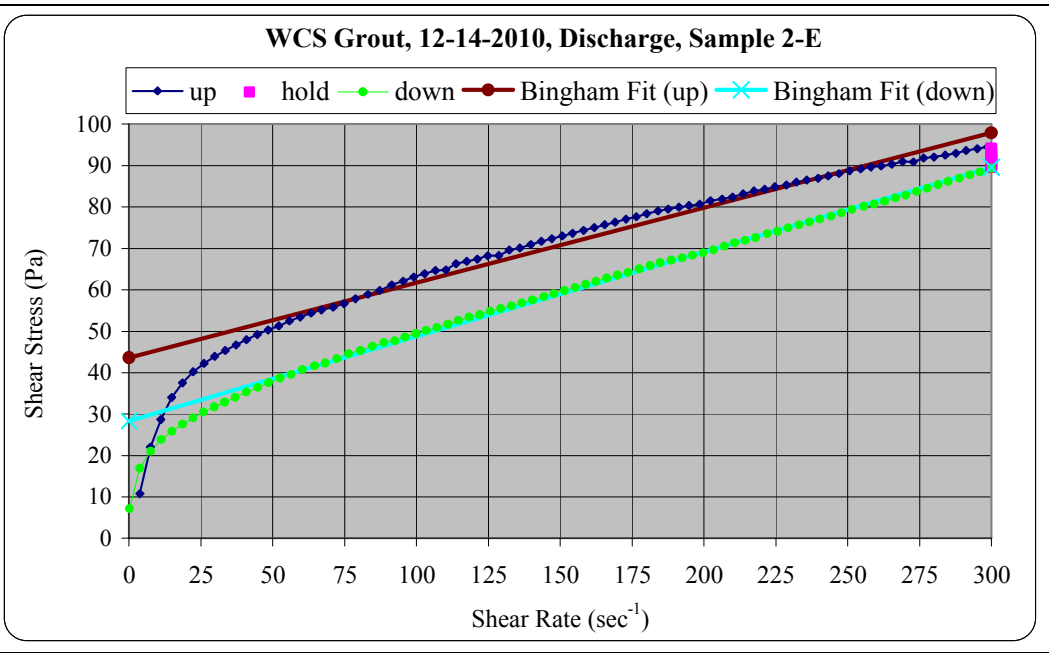

Figure B - 8 BSMR Run 1 - Discharge, Sample 2-E 
Appendix C - Flow Curves from Second BSMR Run 


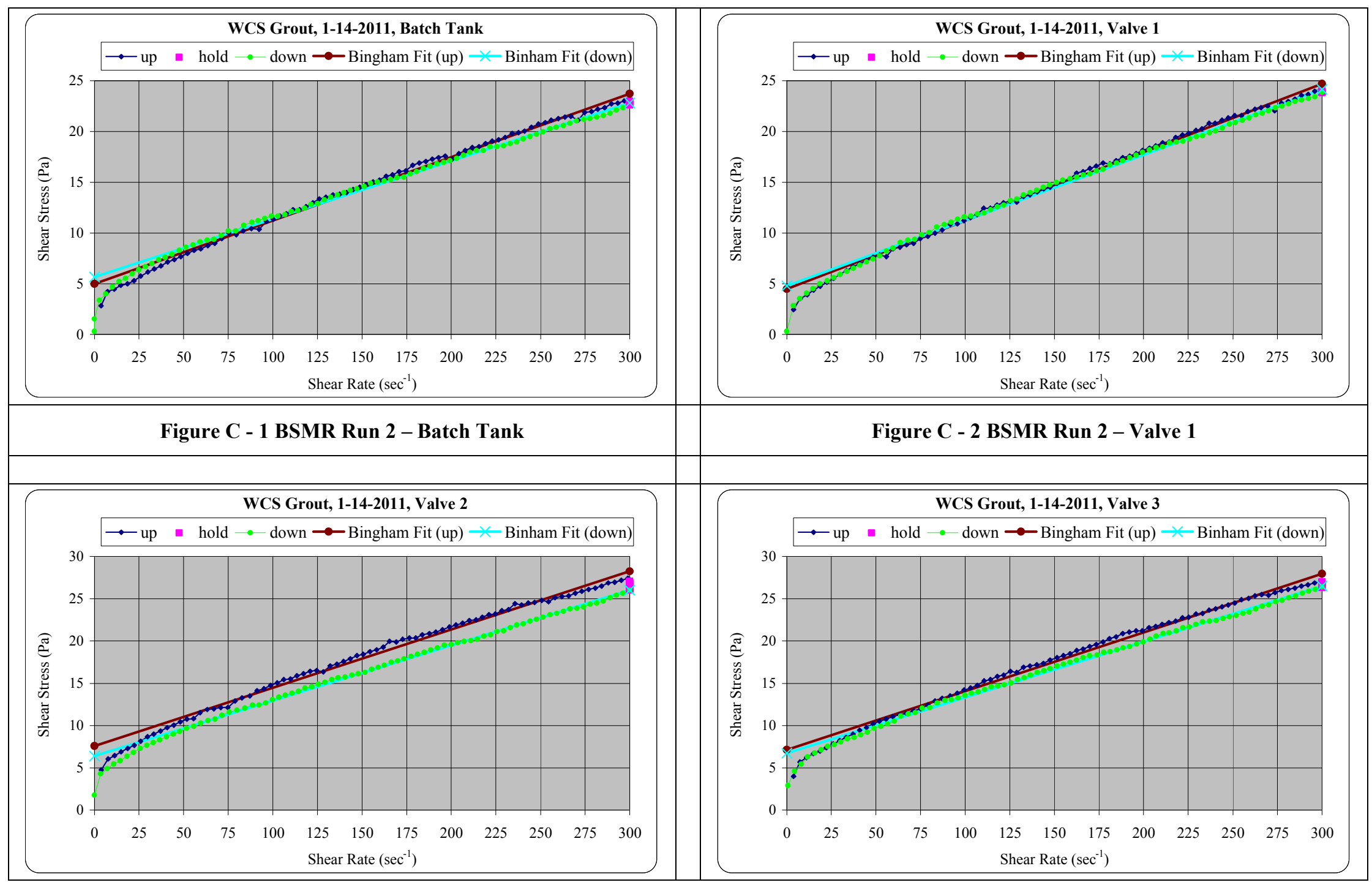




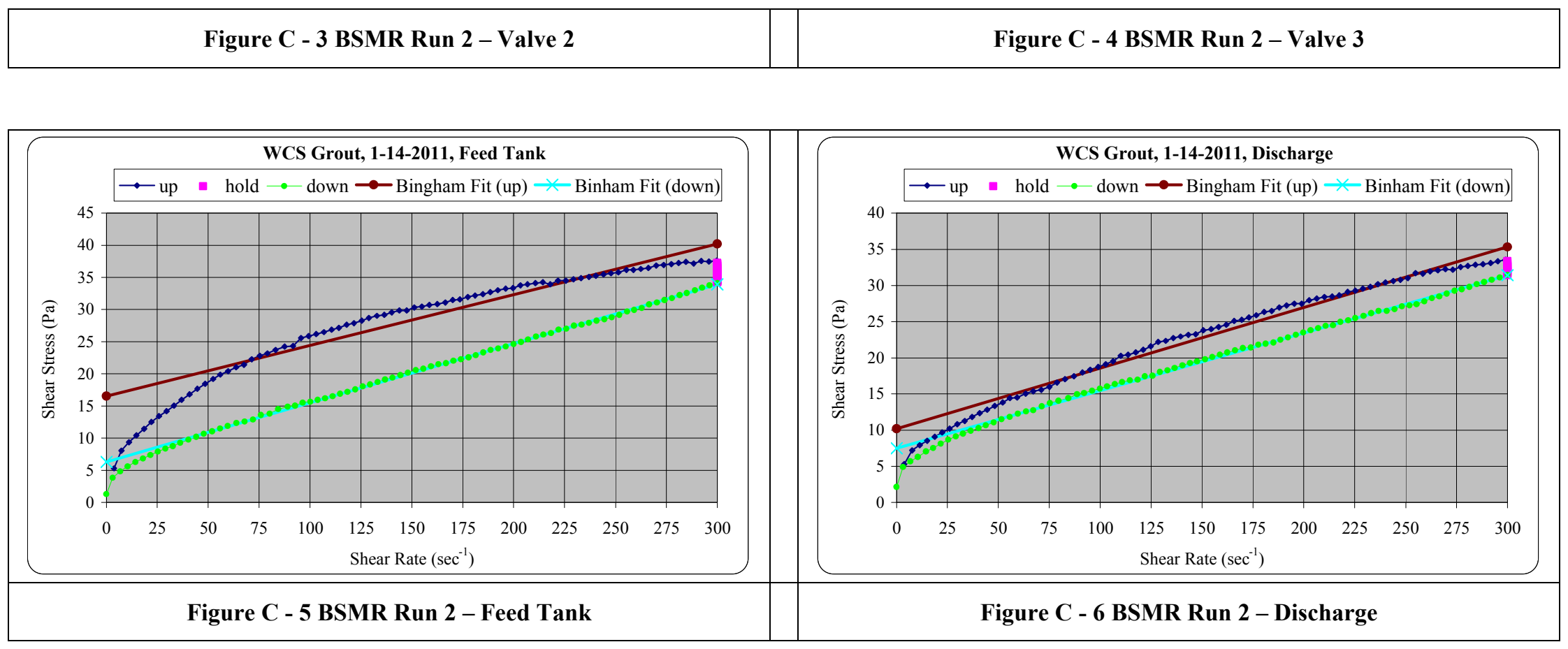

